\title{
Divergent projections of future land use in the United States arising from different models and scenarios
}

\author{
Terry L. Sohl' ${ }^{1}$, Michael C. Wimberly ${ }^{2}$, Volker C. Radeloff ${ }^{3}$, \\ David M. Theobald ${ }^{4}$, Benjamin M. Sleeter ${ }^{5}$ \\ ${ }^{1}$ U.S. Geological Survey, Earth Resources Observation and Science (EROS) Center, $47914252^{\text {nd }}$ \\ Street, Sioux Falls, SD 57198 USA \\ Email: sohl@usgs.gov \\ Phone: 605-594-6537

\begin{abstract}
${ }^{2}$ South Dakota State University, Geospatial Sciences Center of Excellence (GSCE), 1021 Medary Avenue, Brookings, SD 57007 USA 1630 Linden Drive, Madison, WI 53706 USA

${ }^{4}$ Conservation Science Partners, 5 Old Town Square, Fort Collins, CO 80524 USA

${ }^{5}$ U.S. Geological Survey, Western Geographic Science Center, Tacoma WA 98402 USA
\end{abstract} \\ ${ }^{3}$ University of Wisconsin-Madison, SILVIS Lab, Department of Forest and Wildlife Ecology,
}

\begin{abstract}
$\underline{\text { Abstract }}$
A variety of land-use and land-cover (LULC) models operating at scales from local to global have been developed in recent years, including a number of models that provide spatially explicit, multi-class LULC projections for the conterminous United States. This diversity of modeling approaches raises the question: how consistent are their projections of future land use? We compared projections from six LULC modeling applications for the United States and assessed quantitative, spatial, and conceptual inconsistencies. Each set of projections provided multiple scenarios covering a period from roughly 2000 to 2050. Given the unique spatial, thematic, and temporal characteristics of each set of projections, individual projections were aggregated to a common set of basic, generalized LULC classes (i.e., cropland, pasture, forest, range, and urban) and summarized at the county level across the conterminous United States. We found very little agreement in projected future LULC trends and patterns among the different models. Variability among scenarios for a given model was generally lower than variability among different models, in terms of both trends in the amounts of basic LULC classes and their
\end{abstract}


projected spatial patterns. Even when different models assessed the same purported scenario, model projections varied substantially. Projections of agricultural trends were often far above the maximum historical amounts, raising concerns about the realism of the projections.

Comparisons among models were hindered by major discrepancies in categorical definitions, and suggest a need for standardization of historical LULC data sources. To capture a broader range of uncertainties, ensemble modeling approaches are also recommended. However, the vast inconsistencies among LULC models raise questions about the theoretical and conceptual underpinnings of current modeling approaches. Given the substantial effects that land-use change can have on ecological and societal processes, there is a need for improvement in LULC theory and modeling capabilities to improve acceptance and use of regional- to national-scale LULC projections for the United States and elsewhere.

\section{$\underline{1.0 \text { Introduction }}$}

Projections of future land-use and land-cover (LULC) change are useful for scientists, decisionmakers, and other stakeholders who want to understand the effects of LULC change on societal and ecological issues. In recent years, there has been an explosion in both the creation and application of LULC models, operating at scales from local to global. Among these efforts, there are many more local- and regional-scale LULC projections than there are national-scale applications, due to difficulties in producing moderate-to fine-resolution, spatially explicit, multi-class LULC projections for large areas. However, several spatially explicit LULC projections have been produced in recent years for the conterminous United States (Theobald 2005; Bierwagen et al. 2010; Wear 2011; Radeloff et al. 2012; Sohl et al. 2014), plus several global-scale projections that include coverage of the United States. (Strengers et al. 2004; Fujino et al. 2006; van Vurren et al. 2007; Clarke et al. 2007; Riahi et al. 2007; Hurtt et al. 2011; Kram and Stehfest 2012; West et al. 2014; ). Projections of future LULC can enable land managers to visualize future landscapes and optimize landscape planning to account for potential effects on a variety of ecological and social processes (Heistermann et al. 2006), and results from these models have been used to assess biodiversity (Theobald 2005; Sohl 2014, Martinuzzi et al., 2013), hydrology (Viger et al. 2011; Martinuzzi et al. 2014), carbon and biogeochemistry (Zhao 
et al. 2013; Tan et al. 2015), many other ecosystem services (Lawler et al. 2014), and the emergence of novel ecosystems (Martinuzzi et al. 2015) at scales from local to national.

Among current LULC models and projections there is considerable variability in terms of their conceptual underpinnings, scenario frameworks, thematic foci, spatial characteristics, and modeling methodologies. Unfortunately, assessment of different models and modeling approaches is difficult. The lack of reference data for future time periods means that direct validation of LULC models is impossible, and even the quantification of uncertainties in future projections is notoriously difficult (Dendoncker et al. 2008). The complexity, variability, and lack of quantification (or communication) of uncertainty has caused a situation where the LULC models themselves are becoming common, but their actual application for decision-making has been lacking (Couclelis 2005; Zellner 2008; TeBrommelstroet 2010; Sohl and Claggett 2013). Model comparison provides an alternative means for quantifying uncertainty, based on the assumption that confidence in predictions should increase with their consistency across multiple models, and also provides insights into the sensitivity of model outputs to model structure and parameterization (Rastetter, 2003). Schmitz et al. (2014) used such an approach to compare future global trajectories of cropland change projected by 10 different agro-economic land use change models.

In the current study, our goal was to review and compare spatially explicit LULC projections available for the conterminous United States. This continental focus allowed us to explore projected changes for multiple LULC classes, examine the spatial patterns of these projected changes, and assess potential conceptual and methodological issues with current LULC models.

\section{$\underline{\text { 2.0 Data and Methods }}$}

We analyzed publicly available spatially explicit LULC projections covering the conterminous United States (CONUS) (Table 1). Four available sets of projections were specifically designed to model CONUS LULC change. The FORE-SCE projections (named for the use of the FOREcasting SCEnarios of land-use change model) employed a story-and-simulation approach (Alcamo et al. 2006) to produce four spatially explicit LULC scenarios as part of a U.S.

Geological Survey project assessing carbon impacts of LULC change (Sleeter et al. 2012; Sohl et al. 2014). Lawler et al. (2014) used an econometric approach (hereafter referred to as the "NRI 
Econometric Model", due to the model's reliance on National Resources Inventory data (Nusser and Goebel 1997) for model parameterization) to model two baseline and three policy scenarios, and then assess LULC impacts on ecosystem services. The U.S. Forest Service used a similar econometric model to produce three county-based LULC scenarios as part of the Resources Planning Act (RPA) 2010 assessment (Wear 2011) (referred to as the "FS-RPA" hereafter). The Integrated Climate Land Use Scenario (ICLUS) projections used a demographic growth model coupled with a spatial allocation model (Spatially-Explicit Regional Growth model (SERGoM; Theobald 2005) to generate urban land-use scenarios consistent with the Intergovernmental Panel on Climate Change (IPCC's) Special Report on Emissions Scenarios (SRES) storylines (Bierwagen et al. 2010).

At the global scale, integrated assessment models (IAMs) have been used to model LULC interactions with climate and socioeconomic driving forces, typically at coarse spatial resolutions with 0.5 degree or larger grid cells. Scenarios of LULC change for the United States were extracted from four sets of global projections based on IAMs. The Integrated Model to Assess the Global Environment (IMAGE 2.2; Strengers et al. 2004) was used to create global LULC projections consistent with storylines of the SRES ( Nakicenovic and Swart 2001) as part of the IPCC's Fourth Assessment report (AR4). An updated IMAGE 2.4 model was used to produce global LULC projections for the OECD Environmental Outlook to 2050 (Kram and Stehfest 2012; OECD 2012) (referred to as the "OECD" scenarios hereafter). As with the IPCCs AR4 report, four different global integrated assessment models (IAMs) (Smith and Wigley 2006; Riahi et al. 2007; van Vurren et al. 2011; Hijoka et al. 2008) were used to address LULC change for the four Representative Concentration Pathways (RCP) scenarios (Moss et al. 2010) as part of the IPCC Fifth Assessment report (AR5). Hurtt et al. (2011) used these projections and the History Database of the Global Environment (HYDE) LULC database (Goldewijk et al. 2011) to produce harmonized LULC scenarios from 1500-2100, with the harmonization process attempting "to preserve the future changes depicted by the IAMs at the grid cell level." The harmonized Hurtt et al. (2011) data were used here to represent the IAM-modeled RCPs, and are hereafter referred to as the "RCP" projections. Finally, West et al. (2014) used a modeling approach to downscale global-scale projections from the Global Change Assessment Model (GCAM) to the United States, data hereafter referred to as the "GCAM/CONUS" projections. 
Table 1 - Characteristics of the LULC projections covering the conterminous United States.

\begin{tabular}{|c|c|c|c|c|c|c|c|}
\hline & $\begin{array}{l}\text { Temporal } \\
\text { Coverage }\end{array}$ & $\begin{array}{l}\text { Time } \\
\text { Step }\end{array}$ & $\begin{array}{l}\text { Spatial } \\
\text { Resolution }\end{array}$ & $\begin{array}{l}\text { Thematic } \\
\text { Resolution }\end{array}$ & $\begin{array}{l}\text { Geographic } \\
\text { Coverage }\end{array}$ & Scenarios & $\begin{array}{l}\text { Model } \\
\text { Paradigm }\end{array}$ \\
\hline FORE-SCE $^{1}$ & $\begin{array}{l}1992 \text { to } \\
2100\end{array}$ & Annual & $250 \mathrm{~m}$ & 17 classes & $\begin{array}{l}\text { Continental } \\
\text { U.S. }\end{array}$ & 4 (SRES) & $\begin{array}{l}\text { Story-and- } \\
\text { simulation }\end{array}$ \\
\hline $\begin{array}{l}\text { NRI } \\
\text { Econometric } \\
\text { Model }^{2}\end{array}$ & $\begin{array}{l}2001 \text { to } \\
2051\end{array}$ & Start, End & $100 m$ & 5 classes & $\begin{array}{l}\text { Continental } \\
\text { U.S. }\end{array}$ & 5 (Custom) & Econometric \\
\hline FS-RPA $^{3}$ & $\begin{array}{l}1997 \text { to } \\
2060\end{array}$ & 〜Decadal & County & 5 classes & $\begin{array}{l}\text { Continental } \\
\text { U.S. }\end{array}$ & 3 (SRES) & Econometric \\
\hline ICLUS $^{4}$ & $\begin{array}{l}1970 \text { to } \\
2100\end{array}$ & Decadal & $100 m$ & 10 classes & $\begin{array}{l}\text { Continental } \\
\text { U.S. }\end{array}$ & $\begin{array}{l}4 \text { (SRES) + } \\
\text { Baseline }\end{array}$ & $\begin{array}{l}\text { Demographic } \\
\text { and } \\
\text { storylines }\end{array}$ \\
\hline IMAGE SRES $^{5}$ & $\begin{array}{l}1970 \text { to } \\
2100\end{array}$ & Decadal & 0.5 Degree & 19 classes & Global & 4 (SRES) & IAM \\
\hline IMAGE OECD $^{6}$ & $\begin{array}{l}1970 \text { to } \\
2100\end{array}$ & 5 year & 0.5 Degree & 19 classes & Global & 5 (Custom) & IAM \\
\hline $\mathrm{RCP}^{7}$ & $\begin{array}{l}2005 \text { to } \\
2100\end{array}$ & Decadal & 0.5 Degree & Variable & Global & 4 (RCP) & IAM \\
\hline $\begin{array}{l}\text { GCAM } \\
\text { CONUS }^{8}\end{array}$ & $\begin{array}{l}2005 \text { to } \\
2095\end{array}$ & Annual & $\begin{array}{l}0.05 \\
\text { Degree }\end{array}$ & 19 classes & $\begin{array}{l}\text { Continental } \\
\text { U.S. }\end{array}$ & 3 (Custom) & $\begin{array}{l}\text { Downscaling } \\
\text { of IAM }\end{array}$ \\
\hline
\end{tabular}

${ }^{1}$ Sohl et al. $2014 \quad{ }^{2}$ Lawler et al. $2014 \quad{ }^{3}$ Wear $2011 \quad{ }^{4}$ Bierwagen et al. 2010

${ }^{5}$ Strengers et al. $2004 \quad{ }^{6}$ Kram and Stehfest $2014 \quad{ }^{7}$ Hurtt et al. 2011

${ }^{8}$ West and Le Page 2014

Temporal, spatial, and thematic characteristics vary substantially among the different models and projections (Table 1). To facilitate comparisons among the different LULC projections, we standardized each to a common temporal and thematic framework. Temporal intervals for the different frameworks ranged from annual LULC maps to basic beginning- and end-date maps. The starting model dates ranged from 1970 to 2005 and the ending model dates ranged from 2050 to 2100 . Given the variability in temporal characteristics, we limited comparisons to 2000 , 2050, and 2100 (if available). For the nominal 2000 and 2050 dates, the closest date was used from each model. For example, the 1997 FS-RPA date was used to represent the nominal 2000 date for that model, and the 2051 NRI Econometric Model date was used to represent the nominal 2050 date for that model. The NRI Econometric Model, FS-RPA, and IMAGE OECD projection end points were 2051, 2060, and 2050 respectively; thus, no 2100 comparisons were made for these data sets. 
Thematically, most of the projections used different classification schemes, with five to 21 LULC classes. As discussed extensively in the results, varying thematic definitions were a major issue in comparing projection results. However, most, but not all, of the projections could be compared using the five classes mapped by the FS-RPA and NRI Econometric Model (cropland, pasture, forest, range, urban). The individual projections were thus compared at two different levels (Table 2). All projection families were reclassified to allow comparisons for basic "agriculture" and "forest/range." Agriculture was composed of distinctly mapped "cropland" and "pasture" classes for all projection families other than the IMAGE SRES, ICLUS, and GCAM CONUS projections, allowing for a finer thematic scale comparison. Similarly, forest/range was split into "forest" and "range" sub-classes and compared across most projection families. The exceptions were the RCP projections, which did not distinguish forest and range classes, but instead modeled "primary" and "secondary" land. Urban lands were compared for models that explicitly modeled that class (FORE-SCE, NRI Econometric Model, FS-RPA, two of the RCP projections, and ICLUS). ICLUS projections, although using the same SRES scenarios as multiple other models, focused solely on LULC change due to urbanization. As sectoral changes between forest, range, or agriculture were not explicitly modeled (outside of changes resulting from urbanization), only urban results (including the urban and suburban subclasses) are shown for ICLUS.

Table 2 - Reclassification of the projected LULC data sets to aggregate major LULC classes. All LULC projections were aggregated to the major LULC classes of "agriculture" and "forest/range." A majority of projections could also be compared using the finer sub-classes of "cropland" and "pasture" (sub-classes under "agriculture"), and "forest" and "range" (sub-classes under "forest/range"). Most LULC projections included "urban," although the IMAGE-SRES and two of the four RCP models did not.

\begin{tabular}{|r|c|c|c|c|c|c|c|}
\hline Class & FORE-SCE & $\begin{array}{c}\text { NRI } \\
\text { Econometric } \\
\text { Model }\end{array}$ & FS-RPA & $\begin{array}{c}\text { IMAGE } \\
\text { SRES, } \\
\text { OECD }\end{array}$ & RCPs & ICLUS & $\begin{array}{c}\text { GCAM / } \\
\text { CONUS }\end{array}$ \\
\hline 1-Agriculture & & & & Agriculture & & Agriculture & \\
\hline 1a-Cropland & Cropland & Cropland & Cropland & N/A & Cropland & N/A & Crops \\
\hline 1b-Pasture & Pasture & Pasture & Pasture & N/A & Pasture & N/A & \\
\hline
\end{tabular}




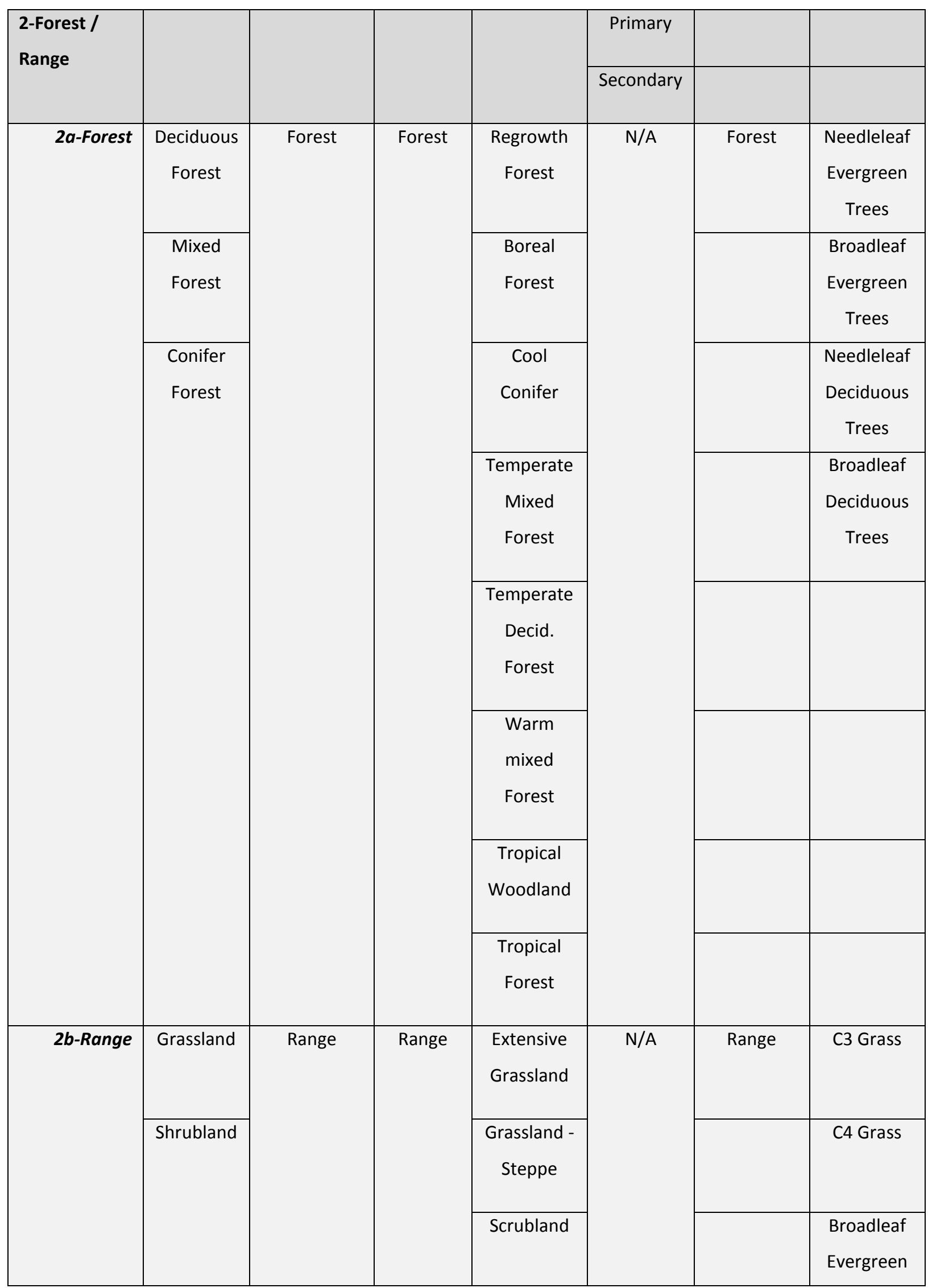




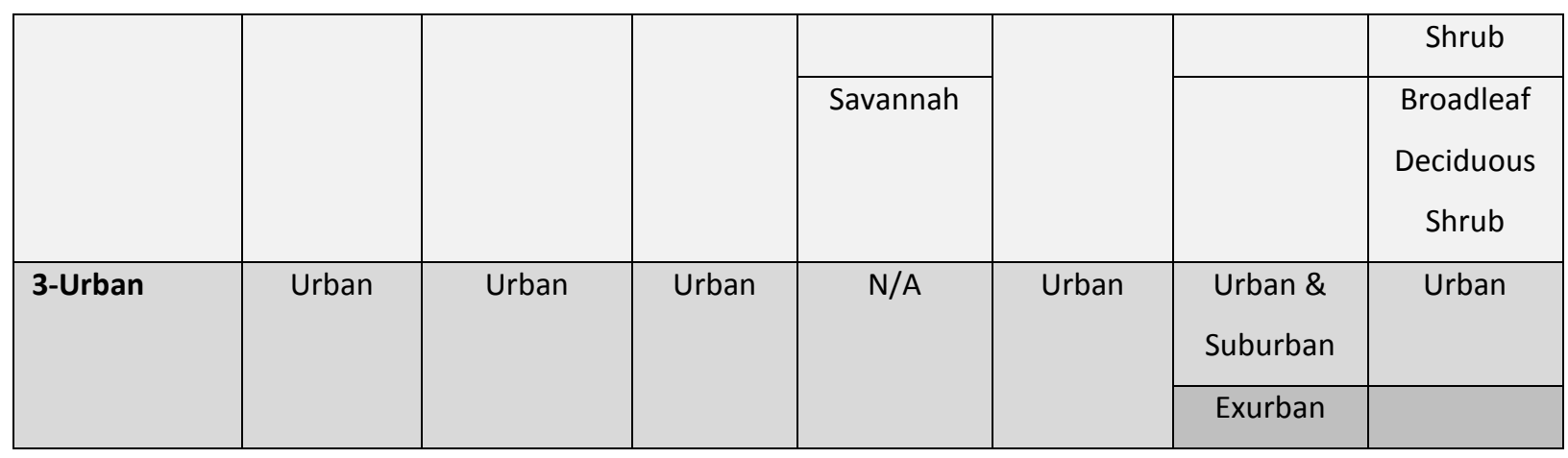

Each model provided multiple scenarios, with each scenario representing a set of future conditions based on internally consistent assumptions about the major drivers, relationships, and constraints that may affect future LULC change (Thompson et al. 2012). Scenarios are typically designed to encompass a range of plausible future trajectories of change, thereby implicitly acknowledging the uncertainty inherent in socioecological systems, rather than attempting to make precise forecasts of future landscapes (Alcamo and Henrichs 2008). Table 3 provides a summary of the scenarios provided by each model. Four models (FORE-SCE, IMAGE 2.2, FSRPA, and ICLUS) used the same scenario framework, the IPCC's SRES. The NRI Econometric Model was used to predict a set of custom projections, including two "baseline" scenarios and three scenarios designed to evaluate different land-use policies (Lawler et al. 2014). As part of the IPCC's original AR5 report used to produce the harmonized Hurtt RCP data set, four different IAMs were used to model each of four different RCP scenarios: IMAGE used for RCP 2.6 (van Vurren et al. 2007; van Vurren et al. 2011), MINICAM used for RCP4.5 (Clarke et al. 2007; Smith and Wigley 2006), AIM used for RCP 6.0 (Fujino et al. 2006; Hijoka et al. 2008), and MESSAGE used for RCP8.5 (Riahi et al. 2007; Rao and Riahi 2006). The fact that multiple models used similar scenarios and other models developed different scenarios allowed us to assess both how a given scenario is interpreted and modeled by different modeling groups, and to compare the variability among scenarios versus variability among models.

Table 3 - Scenarios used by each of the models, and a brief description of the characteristics of each scenario.

\begin{tabular}{|l|l|}
\hline Model & Scenario \\
\hline FORE-SCE, FS-RPA, IMAGE & SRES A1B - Low population growth, high GDP growth, \\
\hline
\end{tabular}




\begin{tabular}{|c|c|}
\hline 2.2, ICLUS & $\begin{array}{l}\text { rapid technological innovation, balanced energy sector, } \\
\text { globalization }\end{array}$ \\
\hline $\begin{array}{l}\text { FORE-SCE, FS-RPA, IMAGE } \\
\text { 2.2, ICLUS }\end{array}$ & $\begin{array}{l}\text { SRES A2 - High population growth, low GDP growth, slow } \\
\text { technological innovation, fossil fuel intensive, regional } \\
\text { growth }\end{array}$ \\
\hline $\begin{array}{l}\text { FORE-SCE, IMAGE } 2.2, \\
\text { ICLUS }\end{array}$ & $\begin{array}{l}\text { SRES B1 - Low population growth, high GDP growth, rapid } \\
\text { technological innovation, renewable energy, globalization }\end{array}$ \\
\hline $\begin{array}{l}\text { FORE-SCE, FS-RPA, IMAGE } \\
\text { 2.2, ICLUS }\end{array}$ & $\begin{array}{l}\text { SRES B2 - Medium population growth, medium GDP } \\
\text { growth, medium technological innovation, mixed energy, } \\
\text { regional growth }\end{array}$ \\
\hline NRI Econometric Model & $\begin{array}{l}\text { 1990s Trend - Continuation of land-use trends from } 1992 \text { to } \\
1997\end{array}$ \\
\hline NRI Econometric Model & $\begin{array}{l}\text { High Crop Demand - Land-use changes accounting for } \\
10 \% \text { increase in crop prices every five years relative to the } \\
\text { 1990s Trend scenario }\end{array}$ \\
\hline NRI Econometric Model & $\begin{array}{l}\text { Forest Incentives -- } \$ 100 / \text { acre annual payment for land } \\
\text { converted to forest; } \$ 100 / \text { acre annual tax for land taken out } \\
\text { of forest }\end{array}$ \\
\hline NRI Econometric Model & $\begin{array}{l}\text { Natural habitats -- } \$ 100 / \text { acre annual tax for land converted } \\
\text { from forest or range to cropland, pasture, or urban }\end{array}$ \\
\hline NRI Econometric Model & $\begin{array}{l}\text { Urban containment - Prohibition on land conversion to } \\
\text { urban in nonmetropolitan counties. }\end{array}$ \\
\hline $\begin{array}{l}\text { Hurtt RCP (originally modeled } \\
\text { with IMAGE) }\end{array}$ & $\begin{array}{l}\text { RCP 2.6 - A "peak-and-decline" scenario, with radiative } \\
\text { forcing peaks at } 3.1 \mathrm{~W} / \mathrm{m}^{2} \text { near } 2050 \text {, declining to } 2.6 \text { by }\end{array}$ \\
\hline
\end{tabular}




\begin{tabular}{|c|c|}
\hline & 2100. \\
\hline $\begin{array}{l}\text { Hurtt RCP (originally modeled } \\
\text { with MiniCAM) }\end{array}$ & $\begin{array}{l}\text { RCP } 4.5 \text { - A stabilization scenario where radiative forcing is } \\
\text { stabilized at } 4.5 \mathrm{~W} / \mathrm{m}^{2} \text { just after } 2100 \text {, using technology and } \\
\text { emission reduction strategies. }\end{array}$ \\
\hline $\begin{array}{l}\text { Hurtt RCP (originally modeled } \\
\text { with AIM) }\end{array}$ & $\begin{array}{l}\text { RCP 6 - A stabilization scenario where radiative forcing is } \\
\text { stabilized at } 6.0 \mathrm{~W} / \mathrm{m}^{2} \text { just after } 2100 \text {, using technology and } \\
\text { emission reduction strategies. }\end{array}$ \\
\hline $\begin{array}{l}\text { Hurtt RCP (originally modeled } \\
\text { with MESSAGE) }\end{array}$ & $\begin{array}{l}\text { RCP 8.5 - Marked by increasing greenhouse gas emissions } \\
\text { over time, leading to very high radiative forcing of } 8.5 \\
\mathrm{~W} / \mathrm{m}^{2} \text {. }\end{array}$ \\
\hline OECD (Image 2.4) & $\begin{array}{l}\text { Baseline - Global population of } 9.2 \text { billion, quadrupling of } \\
\text { GDP, } 80 \% \text { energy demand increase by } 2050 \text {. No new } \\
\text { climate policies. }\end{array}$ \\
\hline OECD (Image 2.4) & $\begin{array}{l}450 \mathrm{ppm} \text { Core - Baseline plus mitigation policy starting in } \\
2013 \text {, designed to stabilize } \mathrm{CO}_{2} \text { concentrations of } 450 \mathrm{ppm} \\
\text { by } 2100 .\end{array}$ \\
\hline OECD (Image 2.4) & $\begin{array}{l}450 \text { ppm Accelerated - Baseline, "Core" mitigation } \\
\text { policies, plus additional mitigation from } 2013 \text { to } 2030 \text {, } \\
\text { designed to stabilize } \mathrm{CO}^{2} \text { concentrations of } 450 \mathrm{ppm} \text { by } \\
2100 .\end{array}$ \\
\hline OECD (Image 2.4) & $\begin{array}{l}450 \text { ppm Delayed - Baseline plus migitation plicy starting } \\
\text { in } 2020 \text {, designed to stabilize } \mathrm{CO}^{2} \text { concentrations of } 450 \\
\text { ppm by } 2100 .\end{array}$ \\
\hline OECD (Image 2.4) & $\begin{array}{l}550 \text { ppm Core - Baseline plus migitation policy starting in } \\
2013 \text {, designed to stabilize } \mathrm{CO}^{2} \text { concentrations of } 550 \mathrm{ppm} \\
\text { by } 2100 .\end{array}$ \\
\hline GCAM & Reference - Business-as-usual with no climate mitigation \\
\hline
\end{tabular}




\begin{tabular}{|l|l|}
\hline GCAM & efforts, radiative forcing $>7 \mathrm{~W} \mathrm{~m}^{-2}$ by 2100. \\
\hline GCAM & $\begin{array}{l}\text { MP 2.6 - Radiative forcing in } 2100 \text { of } 2.6 \mathrm{~W} \mathrm{~m}^{-2} \text {, originally } \\
\text { based on RCP } 2.6 .\end{array}$ \\
\hline $\begin{array}{l}\text { MP 4.5 - Radiative forcing in } 2100 \text { of } 4.5 \mathrm{~W} \mathrm{~m}^{-2}, \text { originally } \\
\text { based on RCP } 4.5 .\end{array}$ \\
\hline
\end{tabular}

The different LULC projections each provide information on overall trends in major LULC classes, as well as a spatial representation of LULC proportions and change. We summarized overall LULC proportions for the entire conterminous United States. for the appropriate LULC classes from Table 2 for the nominal 2000, 2050, and 2100 dates (as available) and evaluated the observed trends in terms of:

1) Consistency in starting proportions for each modeled LULC class,

2) Trajectories of individual LULC classes in Table 2 over time,

3) Variability among different models,

4) Variability among different scenarios within a single model,

5) Consistency in treatment of the "same" scenario by different models.

We also compared the spatial patterns of modeled LULC and LULC change. Spatial characteristics of the different model families varied considerably (Table 1), with spatial resolutions of $100 \mathrm{~m}, 250 \mathrm{~m}, 0.5$ degree grid cells, or county-level. For the NRI Econometric Model, FORE-SCE, IMAGE SRES, and ICLUS data, values were provided as thematically coded grid cells, where each grid cell was assigned a single LULC class. The RCPs and Forest Service RPA provided proportional coverage for the minimum reporting unit ( 0.5 degree grid cell and county, respectively) for each modeled LULC class. Regardless of spatial format, all data sets were rescaled to the county level to facilitate comparison. This "mid-level" spatial framework necessitated the aggregation of the finer-scaled, grid-based FORE-SCE, ICLUS, and NRI Econometric Model projection data, with individual LULC proportions summarized based on the number of grid cells in each county. For the coarser 0.5 degree data provided by the IMAGE SRES and RCP projections, individual counties are smaller than the grid cells in some parts of the conterminous United States. For these data sets, the county-level coverage of each LULC class in Table 2 was determined based on the proportion of each grid cell overlapping the 
county. Although summarizing by county effectively results in an artificial "downscaling" of the IMAGE SRES and RCP data sets, the intention here is not to quantitatively compare all spatial data at a county level, but rather to depict and qualitatively discuss general spatial patterns among the different models and scenarios.

County-level projections of LULC change from 2000 to 2050 for different models and scenarios were compared using pairwise Spearman's rank correlation (Spearman 1904). Using the areas of modeled LULC change for various classes from 2000 to 2050, rank correlation values were calculated across all possible scenario pairs within each individual modeling framework to assess scenario variability. To assess similarity of results for the four models that used the same nominal SRES scenarios (FORE-SCE, Forest Service RPA, IMAGE, ICLUS), pairwise Spearman's rank correlation was also calculated for each possible model pair within a given scenario.

Finally, county-level data for cropland were compared with historical cropland data from the U.S. Agricultural Census (Waisanen and Bliss 2002). Cropland area has varied widely over the last two centuries in many parts of the United States, with estimates of "peak cropland" varying from the 1930s to the 1950s (Theobald 2001; Waisanan and Bliss 2002; Ramankutty et al. 2010). Particularly in the eastern United States, cropland extent was historically far larger than at present. The highest maximum extent of cropland by county was extracted from the Waisanen and Bliss (2002) database and compared with projections in 2050 across models. The intent was to highlight areas where models projected a larger amount of cropland than had ever existed within a county, which may raise questions regarding the realism of a modeled scenario.

\subsection{RESULTS}

\subsection{Conterminous U.S. trends - 2000, 2050, 2100}

We found major differences in the proportions of the seven different LULC classes (three major classes, four sub-classes) for each model (Table 2, Figure 1). Note that not all models are represented for each LULC class, as outlined in Table 2.

3.1.1 - Starting LULC proportion - Substantial variability among models was found in even the most basic measure, the starting proportion of a given LULC class for the nominal 2000 date. 
For example, agriculture (including both cropland and hay/pasture) in 2000 ranged from $~ 1.8$ million $\mathrm{km}^{2}$ to more than 4.0 million $\mathrm{km}^{2}$ (Figure 1A). The cropland component of agriculture varied substantially, from $\sim 1.3$ to $\sim 1.8$ million $\mathrm{km}^{2}$ (Figure 1B), and the pasture component had even greater variability, ranging from less than $500,000 \mathrm{~km}^{2}$ to well over 2 million $\mathrm{km}^{2}$ (Figure 1C). Forest/range varied from $\sim 3.2$ to $\sim 5.0$ million $\mathrm{km}^{2}$ (Figure 1D), with the forest component ranging from $\sim 1.6$ to $\sim 2.3$ million $\mathrm{km}^{2}$ (Figure 1E) and the range component varying from $\sim 1.6$ to $\sim 2.9$ million $\mathrm{km}^{2}$ (Figure 1F). Urban lands in 2000 varied from less than $130,000 \mathrm{~km}^{2}$ to more than $400,000 \mathrm{~km}^{2}$ (Figure 1G). Substantial differences between the thematic classification systems, as well as the use of different source data for 2000 , were the primary drivers behind the variability in initial LULC proportions. Thus, results presented herein must be interpreted within the context of these variable classification systems.

\subsection{2 - Scenario variability - All modeling frameworks}

We found that model choice and underlying model paradigm had a major impact on modeled trends in LULC. For the aggregated agriculture class (Figure 1A), the basic trajectory (i.e., whether a LULC class increased or decreased) varied among scenarios for FORE-SCE, IMAGE, and the RCPs, with about half of the scenarios projecting a decline by 2050 and half projecting a gain. This variability in trajectories was not seen for the FS-RPA, the NRI Econometric Model, or the OECD projections; all scenarios showed the same declining trajectory for agriculture, although the magnitude of the decline varied. For the models that used the IPCC's SRES scenarios, the FS-RPA showed minor declines in agriculture for all scenarios, whereas the FORE-SCE and IMAGE scenarios had large differences in trajectories, with both models depicting some scenarios with agricultural gains and some scenarios with agricultural losses. Cropland (Figure 1B) and hay/pasture (Figure 1C) had high variability among scenarios (with gaining and losing scenarios) for FORE-SCE, IMAGE, and the RCPs and modest declines for all FS-RPA scenarios for both classes. Cropland trends for GCAM increased across all scenarios, while all NRI Econometric Model scenarios other than the "high cropland" scenario depicted cropland declines.

Substantial variability was also seen for the vegetated LULC classes. The aggregate forest/range class showed major differences in trends for FORE-SCE, the NRI Econometric model, IMAGE, the RCPs, and OECD scenarios, with some projecting gains and others losses (Figure 1D). All 
of the FS-RPA and GCAM scenarios exhibited slight declines in forest/range. The forest class (Figure 1E) showed broad variability among scenarios for FORE-SCE, IMAGE, and GCAM. The NRI Econometric Model and OECD scenarios all projected gains in forest area, but the three FS-RPA projections all projected losses. Results were also variable for rangeland (Figure 1F), with FORE-SCE, IMAGE, and OECD models projecting substantial differences in rangeland trends among scenarios, whereas all scenarios for the NRI Econometric Model, the FS-RPA, and GCAM projected declines in rangeland area over time. Projected trends in urban area (Figure 1G) were the most consistent among all models, with each scenario projecting substantial (but variable) increases in urbanized area.

Pairwise Spearman's rank correlations of 2000 to 2050 county-level change for the LULC classes in Table 2 were highly variable for all combinations of scenarios within a given model (Figure 2) and were generally lower for the global IAMs than for the CONUS-only models. Similarity among scenarios was particularly low for the RCPs, where a different IAM and varying scenario assumptions were used for each of the four RCP scenarios, and was also generally low for the IMAGE 2.2 SRES scenarios. FORE-SCE and GCAM showed considerable variation in similarity across scenarios, with some scenario pairs showing strong similarity, but others showing only modest similarity. NRI Econometric Model scenario pairs were more similar than FORE-SCE, but with substantial differences between some scenario pairs, whereas the Forest Service RPA scenarios showed very strong similarity for all possible scenario pairs. The urban LULC class was the most similar between scenario pairs for all models, although the "urban containment" scenario used by the NRI Econometric Model was quite different than other NRI scenarios and resulted in some lower similarity scores.

\subsection{3 - Scenario variability - Different models using the "same" SRES scenarios}

FORE-SCE, the FS-RPA, IMAGE 2.2, and ICLUS all used SRES as the basic scenario framework, allowing us to examine differences in results for what are presumably the "same" scenarios. The basic trajectory of LULC classes was relatively similar between the FORE-SCE and IMAGE projections (Figure 1), which was not a surprise given that IMAGE was used as a primary component in building scenarios for FORE-SCE (Sleeter et al. 2012). However, the magnitude of the changes was quite different, primarily because the very high levels of change projected by IMAGE were deemed to be unrealistic in workshops used to construct FORE-SCE 
scenarios (Sleeter et al. 2012). For example, the trajectory of agriculture was the same for all dates and scenarios between FORE-SCE and IMAGE, but the quantity of modeled change was much higher for IMAGE. Forest and range trajectories were the same for FORE-SCE and IMAGE for three of the four SRES, but again, the magnitude of change varied between the two modeling frameworks. The FS-RPA projections trajectories were quite different from the FORE-SCE and IMAGE results. Agriculture declined modestly in each of the three scenarios modeled by the FS-RPA, a marked difference from FORE-SCE and IMAGE results, where strong increases in agriculture were projected for multiple scenarios. Forest and range both showed similar modest declines for all FS-RPA scenarios, lacking the variability seen in FORESCE and IMAGE results. Urban area was one major LULC class where proportional change was quite similar among FORE-SCE, the FS-RPA, and ICLUS (IMAGE did not model an urban class). There were some differences in the ranking of scenarios based on the amounts of urban change, but in general, the "A" scenarios showed much higher levels of urban change than the "B" scenarios for all models that used SRES.

Pairwise Spearman's rank correlation values of county-level LULC change for each possible model pair for the three SRES modeled by FORE-SCE, the FS-RPA, IMAGE, and ICLUS were again generally low (Figure 3). Even for such broad, aggregate classes as agriculture and forest/range, there was generally very poor agreement among models. Agreement was significantly higher for urban lands for all possible model pairs. Overall for agriculture and forest/range, the two U.S.-focused models (FORE-SCE, FS-RPA) were more similar with one another than with IMAGE. However, given that both the FORE-SCE and FS-RPA applications used a similar scale of analysis and a common starting LULC framework based on the National Land Cover Database (NLCD; Vogelmann et al. 2001; Homer et al. 2007), the overall similarity for a given SRES scenario was modest at best. FORE-SCE and IMAGE showed strong disagreement at a county level, which was surprising given the very similar trajectories of overall LULC between the two models. Disagreement between FORE-SCE and IMAGE was largely due to differences in spatial patterns of change.

\subsection{Spatial patterns of change - 2000, 2050, 2100}

Not only did national-level proportions and trends of individual LULC classes vary greatly among models, but so did the spatial patterns of modeled LULC change, as indicated by the 
county-level pairwise Spearman's rank correlations (Figures 2,3) and maps of changes in cropland, pasture, forest, and range (respectively) from the nominal 2000 and 2050 dates (Figures 4-8). The spatial patterns of modeled cropland change for FORE-SCE, the NRI Econometric Model, the FS-RPA, and GCAM each showed distinctive regional patterns within a given model, regardless of modeled scenario (Figure 4). For example, the FORE-SCE A1B and A2 scenarios both projected an overall increase in cropland proportion by 2050, showing most of the increase occurring in the Great Plains. The FORE-SCE B1 and B2 scenarios both projected modest declines in overall cropland proportions by 2050, yet local patterns of cropland gain mimicked the heaviest areas of cropland gain from the A1B and A2 scenarios (Figure 4). The NRI Econometric Model projections also showed spatial similarity among scenarios, with all scenarios depicting cropland gains in the same general areas of the West and in Texas, whereas the same patterns of cropland loss were seen across all scenarios in parts of the Great Plains and Midwest. Cropland change was very modest for the FS-RPA projections, but again, the same spatial patterns were present across all scenarios. GCAM scenarios all show strong cropland gain in the western half of the conterminous United States. The RCP scenarios were the only ones that showed variability in spatial pattern among scenarios. However, the RCPs are unique in that each scenario was originally modeled using a different IAM, and it is likely that the differences in spatial pattern between scenarios were due at least in part to the underlying models that were used, in addition to the different scenario characteristics.

Spatial patterns of change differed strongly among models for other land-cover classes as well. Patterns of modeled 2000 to 2050 pastureland change (Figure 5) showed the same regional biases for FORE-SCE, the NRI Econometric Model, and the FS-RPA, whereas the multi-model approach used for the RCPs resulted in broad variability in spatial patterns of pastureland change. Forest and rangeland patterns (Figures 6 and 7) were also similar among scenarios for a given model, but with distinctive regional biases present for each of the models that explicitly modeled these classes The two model sets that appear most similar in Figures $\mathbf{6}$ and $\mathbf{7}$ are the IMAGE 2.2 and OECD results, perhaps not surprising given that the OECD scenarios were modeled with an updated version of IMAGE (IMAGE 2.4). Urban patterns (Figure 8) show the most similarity across model families. This is not surprising given the localized nature of urbanized landscapes and the limited geographic area where urban change is likely. However, even for urban lands, projections are much more similar among scenarios within a given model 
than they are among projections across different models. . Overall, the comparisons indicated a very strong influence of model choice on spatial patterns of change, with each model exhibiting a distinctive spatial signature despite the large differences among the scenarios used for each model (Figures 4-8).

\subsection{Comparison of model results versus historical data sets}

Results for the different models that explicitly modeled cropland were compared with historical cropland extent data by county to highlight areas where models were projecting quantities of cropland that exceeded any historical maximum (Figure 9). Given differences between the U.S. Agricultural Census data (Waisanen and Bliss 2002) and the starting point LULC data sets used by the various models, some counties surpassed the "historical maximum" from the Agricultural Census right at the start of the simulation, before any modeling occurred (Figure 9), and many counties were projected to surpass the historical maximum by 2050. For the FORE-SCE model, the A1B and A2 scenarios were characterized by large increases in modeled cropland by 2050, resulting in a number of counties in the Great Plains surpassing the maximum historical cropland extent. For the NRI Econometric Model projections, only the "high cropland" scenario projected an increase in cropland, yet, several of the same counties (primarily in the southwestern United States and Texas) were projected to surpass the historical cropland maximum by 2050 in all scenarios, even scenarios that projected overall cropland loss. The FS-RPA scenarios were all similar, showing modest cropland declines; as a result, no counties were projected to surpass historical cropland maxima by 2050. Of the RCPs, only RCP2.6 projected any significant increase in cropland by 2050, but as Figure 9 indicates, that modeled increase in cropland resulted in many counties in the western United States surpassing the maximum level of historical cropland. As with the RCPs, GCAM projections had many counties that exceeded historical cropland levels at the start of the simulation period. However, each of the GCAM scenarios projected large cropland gains in the western United States, resulting in many counties exceeding historical maximums by 2050 .

\subsection{DISCUSSION}

We found very little agreement in projected land-use trends and patterns from the different models that we analyzed. One of our greatest difficulties in comparing models was simply 
accounting for varying thematic definitions between model applications and the use of different starting LULC data sets. These differences are evident in Figure 1, where starting LULC proportions are substantially different among the different types of models. Differences are

particularly evident when comparing CONUS-only models versus the IAMs. For example, due to definitional differences (e.g., a broader definition of "pasture" for IAMs) and a reliance on different source LULC data sets (e.g., HYDE-based starting LULC for multiple IAMs versus NLCD-based LULC for multiple CONUS-only models), the IAM models typically represent more land in cropland and/or pasture than do the CONUS-only models. These differences complicate efforts to directly compare results from different models. Initial LULC proportions may be different among modeling frameworks, but we can still make valid comparisons of LULC trends and spatial patterns among the different modeling frameworks as discussed below, particularly when comparing among IAMs by themselves or CONUS-only models by themselves. These comparisons allow us to identify several issues that impact the development and application of LULC models.

\section{1 - Need for standardized data and assessment frameworks}

A number of factors hinder cross-model and cross-scale comparisons, including the use of different source LULC data, inconsistent thematic definitions, differences in spatial scale, and differences in modeling initialization date. Overall, these disparities erode confidence in LULC models, increase the perception of uncertainty, and limit our ability to quantify uncertainty in LULC models. These differences also limit the possibility to establish any kind of ensemble approach for LULC modeling. A multi-scale standardization of LULC definitions, dataset "crosswalks" (methods to thematically and/or spatially convert between disparate LULC data sets), and reporting methods would greatly improve our ability to perform cross-model comparisons, conduct multi-model approaches, and quantify modeling uncertainties.

Currently, the field of LULC modeling lags behind other disciplines in terms of standardization. The National Research Council (2013) stated that the primary research needs for LULC modeling were developing common model infrastructures that serve as platforms for understanding LULC change processes and evaluating resultant effects on ecological and societal processes. In climate modeling, there is certainly variability among modeling frameworks, yet there is also a long history of intercomparisons among models (Lambert and 
Boer 2001; Covey et al. 2003), with recent work such as the Coupled Model Intercomparison Project Phase 5 (CMIP5) providing a framework for integrating and assessing climate model differences (Taylor et al. 2012). Similarly, for species distribution modeling (SDM), the Software for Assisted Habitat Modeling (SAHM) and the R package biomod2 were developed to provide a consistent, repeatable means for ingesting standardized data inputs and using them to develop and compare multiple SDMs and make ensemble predictions (Thuiller 2003; Thuiller et al. 2009; Stohlgren et al. 2010). For carbon and biogeochemical modeling, the North American Carbon Program (NACP) has developed protocols for synthesizing and comparing many different terrestrial biosphere models, to understand causes of model variability (Huntzinger et al. 2012).

Our basic spatial and qualitative comparisons of the handful of LULC models that have produced projections for the conterminous United States represents a step in this direction for LULC modeling, but more comprehensive comparison programs are needed. Efforts such as the U.S. National Vegetation Classification (USNVC) are moving in this direction, as they provide a framework for documenting, monitoring, and assessing vegetation in the United States (http://usnvc.org). More recently, the Land-use Model Intercomparison Project (LUMIP) has been established as part of CMIP to address relationships between land use, climate, and biogeochemical cycling at a global scale, including metrics to quantify and diagnostically assess sensitivities and uncertainties related to land-use models (https://cmip.ucar.edu/lumip). Efforts such as these suggest a path forward for providing 1) consistent model inputs for regional- and national-scale LULC modeling, 2) common sets of scenarios, and 3) methodologies for model intercomparison.

\subsection{Interpreting results in the context of model purpose}

One major reason for differences in model outputs are differences in model purpose. With the variety of model structures, data requirements, and conceptual elements, model choice must be aligned with the intended purpose (Brown et al. 2013). The models used for the global IAM results presented here (IMAGE, RCPs, OECD, GCAM) strive to represent interactions between climate, demographics, land use, energy, policy, and more for all socioeconomic sectors across the entire globe. A global model is unlikely to lead to results that match those from models solely focused on the United States, and the IAMs are primarily designed to support climate 
modeling rather than focus exclusively on LULC. For models that attempt to account for a multitude of driving forces, a concern is the substantial inconsistencies among different IAMs. Scenario differences clearly account for many of these inconsistencies, but as with all models examined here, spatial patterns of change vary widely among models. These results also indicate potential issues with "realism" of global-scale models at a regional or national scale, such as a projected near-doubling of agricultural land by 2100 in the IMAGE A2 scenario or widespread expansion of cropland in the dry interior western United States in the RCP2.6 and GCAM scenarios.

The two econometric modeling approaches (NRI Econometric Model and Forest Service RPA) were designed to assess policy effects on economic returns of various LULC classes, which in turn affect the rates and spatial patterns of LULC change. Given similarities in basic model structure, it is surprising how different projected patterns were for these two models when accounting for the use of different scenarios. The Forest Service RPA projections focused more on population growth scenarios and the effects of resulting urban growth on other land uses, whereas the NRI Econometric Model projections were driven mostly by the feedbacks of policy changes on the economic returns of various land uses and the resulting land-use decisions. These differences emphasize how even for two models built upon a similar econometric framework, modeling decisions about the types of land-use drivers and relationships to emphasize can translate into substantial differences in the amount and spatial pattern of projected change.

The FORE-SCE model is an empirical-statistical model that downscaled scenarios consistent with IPCC SRES to regionally relevant scales, in support of a national-level assessment of carbon dynamics. For the FORE-SCE model, among-scenario variability was substantially higher than for the other U.S.-specific models. That finding was not unexpected, given that the FORE-SCE projections were specifically designed to capture a wide range of potential LULC outcomes. However, as with all of the models we examined, a possible concern is the similar, strong spatial patterns present across all scenarios. The similarity in spatial patterns evident within a given model's suite of scenarios, compared with the strong variability in spatial patterns among different models, indicates the substantialinfluence of model choice in defining overall landscape pattern.

\section{3 - Multi-scenario versus Multi-model approaches}


In LULC modeling, scenarios are alternative visions of the future, and multiple scenarios are employed to capture a range of future LULC conditions (Peterson et al. 2003; Verburg et al. 2008; Moss et al. 2010). Given the variety of scenarios and approaches compared here, variability among model projections was to be expected. However, we were surprised that variability among scenarios of each model was generally much lower than variability among the models themselves. Results suggested that the range of scenarios employed for each model most likely did not bound the full range of potential landscape outcomes. For some models, the same trajectories were projected regardless of modeled scenario (e.g., cropland and forest for the NRI Econometric Model, FS-RPA). Spatial patterns of change (Figures 4-8) were very similar across scenarios for a given model, a characteristic likely due to the reliance on common data sources and common forms of parameterization, regardless of scenario characteristics. For example, each scenario modeled by FORE-SCE used the same probability-of-occurrence surfaces to drive the spatial arrangement of landscape change, each scenario modeled by the NRI Econometric Model or the FS-RPA relied on the same county-level parameterization based on NRI data, and most of the IAMs relied on the same limited set of biophysical parameters to establish site-level suitability for a given LULC class. In addition to model mechanics, different researchers make subjective judgements in scenario and model parameterization and execution (Rounsevell et al. 2006), and many of those subjective judgements are never communicated in published results. In effect, each scenario is a model within a model, a subjectively interpreted representation of a likely LULC outcome based on a particular set of assumptions. Although the role of scenarios is to assess variation in possible futures, the range of variability in actual modeling outcomes is generally reduced by common paradigms used by an individual model or modeling team (Metzger et al. 2010). "Scenario convergence" (Metzger et al. 2010) due to model and modeler biases can reduce the range of plausible futures within an individual set of projections, and is likely one reason for our results suggesting that the paradigms and/or biases of an individual model and modeling research team can play a bigger role than the scenarios themselves.

Clearly, a multiple-scenario approach using a single LULC model (e.g., the approach used by all frameworks assessed here other than the RCPs) is not likely to capture most of the modeling uncertainty in projecting future LULC. Conversely, a multi-model approach, where a different model is used for each scenario (e.g., the approach used by the RCPs), renders any comparison 
between scenarios extremely difficult, given the very strong influence of model choice on projection results. An ideal approach would use 1) multiple scenarios, to capture uncertainty related to potential future pathways of future LULC change, and 2) multiple models for each scenario, to capture uncertainty and bias present in any one modeling framework. We recognize, however, that there are substantial barriers to instituting a multi-scenario, ensemble approach for LULC modeling, including 1) lack of publicly available code for many models, 2) lack of standardization of model inputs and forms of predicted output, and 3) increased time, personnel, and computing costs. However, as these results suggest, any attempt to quantify LULC modeling uncertainties will likely result in severe underestimates with the modeling approaches currently being used.

\section{$\underline{4.4 \text { - "Realism" of modeled scenarios and use of historical data }}$}

Historical U.S. Agricultural Census data (Waisanen and Bliss 2002) allowed us to flag areas where modeled cropland extent might be unrealistic. The aforementioned differences between thematic definitions and starting LULC datasets resulted in IAMs exceeding maximum historical cropland extent for many counties, before modeling even began (Figure 9). However, even when normalizing to initial cropland proportions as provided by the U.S. Agricultural Census data, the FORE-SCE A1B and A2, NRI Econometric model "High Cropland," and RCP 2.6 scenarios would all result in total CONUS cropland surpassing the 1940 cropland peak noted in Waisanen and Bliss (2002). Surpassing historical cropland maximums at a local or regional level certainly is not impossible, and recent cropland expansion in the northern Great Plains is an indication that favorable economic conditions can drive rapid growth in agricultural land (Wright and Wimberly 2013; Lark et al. 2015). Scenario storylines may also introduce novel conditions not represented in historical landscapes; for example, FORE-SCE's A1B scenario describes technological advancement that enables a rapid expansion in the use of marginally productive lands for the cultivation of cellulosic biofuel feedstocks such as switchgrass (Sleeter et al. 2012; Sohl et al. 2014). Other modeled scenarios also assume widespread cultivation of second generation biofuel crops, potentially altering traditional spatial distributions of "cropland" across the conterminous United States and enabling cropland areas to surpass historical maximums. However, while second-generation biofuel crops may expand overall cropland production in the 
United States, there are still biophysical and economic limitations to where those new crops may be grown. Switchgrass (Panicum virgatum) and Miscanthus (Miscanthus x giganteus) are the two most widely studied cellulosic feedstocks, but biophysically suitable areas for economically feasible levels of productivity are primarily limited to the eastern United States and the eastern Great Plains (McLaughlin and Kszos 2005; Gunderson et al. 2008; Miguez et al. 2012). Several of the model results here, including both IAMs and CONUS-only models, show strong cropland expansion in the interior West, an arid area that is poorly suited for either traditional or second generation biofuel crops.

Other factors also bring into question the feasibility of broad-scale cropland expansion in many parts of the CONUS. At a regional level, substantial areas of former cropland have been permanently converted to urbanized or other land uses, reducing the potential pool of land suitable for cropland. Models may also neglect to account for driving forces and feedbacks that limit a given land use, such as cropland. For example, groundwater depletion in the High Plains aquifer is likely to substantially reduce the extent of irrigated cropland in parts of the western Great Plains in the coming decades (Steward et al. 2015). Neither the FORE-SCE or NRI Econometric models accounted for projected changes in groundwater availability to constrain LULC change; select scenarios from both models project very strong cropland gains in the very locations where Steward et al. (2015) have predicted substantial declines in saturated thickness of the aquifer. As noted above, these areas are also unlikely to support newer, second-generation biofuel crops.. The primary modeling scale may also affect the "realism" of LULC projections. Global-level IAMs may capture broad-scale driving forces that affect demand for crop commodities, but poorly represent local-scale suitability of the land to support cropland. On the other hand, regional- and national-scale models may neglect to incorporate broad-scale driving forces that may limit overall demand for a given land use. For example, the NRI Econometric Model and the FS-RPA are strongly driven by county-level economic variables and may not include broader-scale driving forces that may limit agricultural expansion. Comparing modeled results to data such as maximum historical cropland extent may help to flag potential issues with model "realism," and the historical data may be useful to help constrain model scenarios.

\section{5 -LULC change theory}


Whereas a multi-model approach may increase our understanding of modeling uncertainty, the broad differences in model results reported here suggest that it is not just model choice that leads to high overall uncertainty. For example, the SRES framework used by FORE-SCE, IMAGE, FS-RPA, and ICLUS provided broad demographic, socioeconomic, and climate-based storylines. The very different results among applications that were supposedly modeling the "same" scenarios imply conceptual or theoretical inconsistencies in modeling landscape response to a common set of driving forces. Each of these models used different approaches to incorporating SRES storylines, but the one commonality across all models is that uncertainties in model results are poorly understood. Of the models that used SRES, the IMAGE 2.2 model likely attempted to address the widest array of driving forces, with linked sub-models covering demographics, the energy sector, climate, land use, and other biophysical and socioeconomic driving forces. While the theoretical basis of each individual sub-model may or may not have been sound, sensitivities and the theoretical underpinnings of the model linkages were not assessed, nor were uncertainties that propagated throughout the entire IMAGE model (Bouwman et al. 2006). The FORE-SCE modeling of SRES used a downscaling of IMAGE 2.2 as one component of the scenario construction, but also relied heavily on regional land-use histories and expert knowledge to "correct" elements of IMAGE that were perceived to be unrealistic. This empirical and expertbased adjustment of IAM output may have produced more realistic results at the scale of the conterminous United States, but the theoretical basis for the projected landscape change was poorly described and modeling uncertainties were not quantified. The FS-RPA also downscaled IAM output for the SRES, adapting IAM outputs based on U.S. projections of population and Gross Domestic Product and relying heavily on those components to model county-level change with an econometric model based on historical data from 1987 to 1997 . While based on theoretical assumptions related to economic returns, other relevant driving forces were excluded, there were no attempts to justify temporal stationarity of model parameterization based on the short historical time frame, and modeling uncertainties were not quantified. The ICLUS model focused on urban growth using SRES to describe broad demographic trends and serve as input to a county-level gravity model to represent population growth and domestic migration. As with many land-use models, ICLUS assumed temporal stationarity and relied on past land-use patterns to drive future change. The focus on urbanization processes inadequately represented potential competition with other land uses, and modeling uncertainties were not comprehensively 
quantified. All of these approaches relied on a series of assumptions, without supporting sensitivity analyses or other quantitative evaluation. Coupled with poorly described modeling uncertainties, not only is it difficult to rationalize the theoretical underpinnings of each model, but it is impossible to quantitatively assess model results and use well-defined model uncertainties to understand and improve the theoretical basis of the models.

The issues noted above are not meant as harsh critiques of the individual models. There clearly is no "perfect" land-use model that is theoretically sound and accounts for all relevant driving forces of landscape change, without error or bias. Each of the aforementioned models necessarily made compromises in how land-change processes were represented, and as a result, each was theoretically deficient in one way or another. What are the implications of these broad differences among models and modeling teams? The results indicate the difficulty in translating global-level scenarios to regional scales and, also highlight potential deficiencies in basic landchange theory. Theoretical constructs attempting to define pathways of landscape change have been introduced in the last 20 years, such as forest transition theory (Mather and Needle 1998) and teleconnected land systems (Meyfroidt et al. 2010; Seto et al. 2012). Recommendations have been made to represent these dynamics in LULC models (Brown et al. 2013; National Research Council 2013), but LULC modeling applications have not been very successful in incorporating these concepts and providing consistent outcomes. Our results showed tremendous disparity in outputs from models such as the global IAMs that do attempt to address a large array of driving forces, including feedbacks and teleconnections across space. At a more basic level, it can be difficult to simply identify what are the relevant driving forces. Rounsevall (2012) proposed three major research questions as the way forward for land system science, one of which was "What are the socio-economic and ecological processes that shape land-use transitions?" Given our continued inability to definitively answer this basic question, it is not surprising that different models may have difficulty in consistently quantifying the impacts of driving forces on LULC change. The very fact that LULC modelers rely heavily on a "storyline" approach to scenarios and modeling, as opposed to more objective, process-based modeling, in part reflects the large uncertainties involved with projecting future LULC. Our inability to assess and quantify modeling uncertainties greatly inhibits our ability to use model results as a means for understanding and improving the theoretical basis of our LULC models. In short, our 
ability to monitor and empirically model LULC change has far outpaced our theoretical understanding of the processes driving LULC change.

\subsection{CONCLUSIONS}

Our comparison of the output from several LULC models for the conterminous United States showed very little agreement in projected trends and patterns, highlighting the considerable effect that model choice has on results. Not only did results reveal potential weaknesses in the LULC models themselves, they also suggested a strong need for a much greater investment in developing land-change theory and incorporating it into quantitative spatial models of land-use change. Current scenario-based approaches suffer from inconsistencies in the interpretation of the impacts of driving forces on basic LULC trends, variable thematic definitions of land-use and land-cover classes, failure to assess results in the context of historical patterns of LULC change, , and 'scenario convergence' that likely results in an underestimation of true modeling uncertainties.

LULC models clearly serve a purpose, and despite the issues noted in this paper, existing LULC projections are being used for many practical applications. However, given the importance of future landscape change on a host of ecological and societal processes, improvements are needed, including the use of ensemble-based approaches to improve the representation of uncertainties, development of standardized data and assessment frameworks, increased integration of historical data sources to improve realism of modeled results, and refinement of land-change theory to enable translation of driving forces into quantitative land-change algorithms.

\section{Acknowledgments}

The authors thank the USGS Climate and Land Use Change Mission Area's Research \& Development and Land Change Science programs, and the National Science Foundation's Coupled Natural and Human Systems program for supporting this work. Thank you to V. Landau for data processing support. 


\section{$\underline{\text { References }}$}

Alcamo, J., Kok, K., Busch, G., Priess, J.A., Eickhout, B., Rounsevell, M., Rothman, D.S., and Heistermann, M., 2006. Searching for the future of land: Scenarios from the local to global scale, in Land-use and Land-cover Change - Global Change - The IGBP Series, E.F. Lambin and H. Geist, eds., Springer Berlin Heidelberg, p 137-155.

Alcamo, J., and Henrichs, T., 2008. Towards guidelines for environmental scenario analysis. Developments in Integrated Environmental Assessment 2: 13-35.

Bierwagen, B.G., Theobald, D.M., Pyke, C.R., Choate, A., Groth, P., Thomas, J.V., and Morefield, P., 2010. National housing and impervious surface scenarios for integrated climate impact assessments. Proceedings of the National Academy of Sciences USA 107(49): 2088720892.

Bouwman, A.F., Kram, T., and Goldewijk, K.K., 2006. Integrated modeling of global environmental change: an overview of IMAGE 2.4. Netherlands Environmental Assessment Agency (MNP), Bilthoven. MNP publication number 500110002/2006.

Brown, D.G., Verburg, P.H., Pontius Jr., R.G., and Lange, M.D., 2013. Opportunities to improve impact, integration, and evaluation of land change models. Environmental Sustainability 5: 452457.

Clarke, L., Edmonds, J., Jacoby, H., Pitcher, H., Reilly, J., and Richels, R., 2007. Scenarios of greenhouse gas emissions and atmospheric concentrations. Sub-report 2.1A of Synthesis and Assessment Product 2.1 by the U.S. Climate Change Science Program and the Subcommittee on on Global Change Research. Department of Energy, Office of Biological \& Environmental Research, Washington, D.C. 154 pp.

Covey, C., AchutaRao, K.M., Cubasch, U., Jones, P., Lambert, S.J., Mann, M.E., Phillips, T.J., and Taylor, K.E., 2003. An overview of results from the coupled model intercomparison project. Global and Planetary Change 37: 103-133.

Dendoncker, N., Schmit, C., and Rounsevell, M., 2008. Exploring spatial data uncertainties in land-use change scenarios. International Journal of Geographical Information Science 22(9): 1013-1030.

Couclelis, H., 2005. Where has the future gone? Rethinking the role of integrated land-use models in spatial planning. Environment and Planning A 37: 1353-1371.

Fujino, J., Nair, R., Kainuma, M., Masui, T., and Matsuoka, Y., 2006. Multi-gas mitigation analysis on stabilization scenarios using AIM global model. Multigas Mitigation and Climate Policy. The Energy Journal Special Issue 27: 343-353.

Goldewijk, K., Beusen, A., van Drecht, G., and de Vos, M., 2011. The HYDE 3.1 spatially explicit database of human induced land use change over the past 12,000 years. Global Ecology and Biogeography 20: 73-86.

Gunderson, C.A., Davis, E.B., Jager, H.I., West, T.O., Perlack, R.D., Brandt, C.C., Wullschleger, S.D., Baskaran, L.M., Wilkerson, E.G., and Downing, M.E., 2008. Exploring Potential U.S. 
Switchgrass Production for Lignocellulosic Ethanol. U.S. Department of Energy, Oak Ridge National Laboratory, Oak Ridge, Tennessee. ORNL/TM-2007/183

Heistermann, M., Muller, C., and Ronneberger, K., 2006. Land in sight? Achievements, deficits, and potentials of continental to global scale land-use modeling. Agriculture, Ecosystems, and Environment 114: 141-158.

Hijoka, Y., Katsumoto, Y., Hishimoto, H., Masui, M., and Kainuma, M., 2008. Global GHG emissions scenarios under GHG concentration stabilization targets. Journal of Global Environmental Engineering 13: 97-108.

Homer, C. Dewitz, J., Fry, J., Coan, M., Hossain, N., Larson, C., Herold, N., McKerrow, A., Van Driel, J.N., and Wickham, J.,2007. Completion of the 2001 National Land Cover Database for the Conterminous United States. Photogrammetric Engineering and Remote Sensing 73, 337341 .

Huntzinger, D.N., Post, W.M., Wei, Y., Michalak, A.M., West, T.O., Jacobson, A.R., Baker, L.T., Chen, J.M., Davis, K.J., Hayes, D.J., Hoffman, F.M., Jaim, A.K., Liu, S., McGuire, A.D., Neilson, R.P., Potter, C., Poulter, B., Price, D., Raczka, B.M., Tian, H.Q., Thornton, P., Tomelleri, E., Viovy, N., Xiao, J., Yuan, W., Zeng, N., Zhao, M., and Cook, R., 2012. North American Carbon Program (NACP) regional interim synthesis: Terrestrial biospheric model intercomparison. Ecological Modelling 232: 144-157.

Hurtt, G.C., Chini, L.P., Frolking, S., Betts, R.A., Feddema, J., Fischer, G., Fisk, J.P., Hibbard, K., Houghton, R.A., Janetos, A., Jones, C.D., Kindermann, G., Kinoshita, T., Goldewijk, K.K., Riahi, K., Shevliakova, E., Smith, S., Stehfest, E., Thomson, A., Thornton, P., van Vuuren, D.P., and Wang, Y.P., 2011. Harmonization of land-use scenarios for the period 1500-2100: 600 years of global gridded annual land-use transitions, wood harvest, and resulting secondary lands. Climatic Change 109: 117-161.

Kram, T., and Stehfest, E., 2012. The IMAGE model suite used for the OECD Environmental Outlook to 2050. PBL Netherlands Environmental Assessment Agency, Bilthoven p. 44.

Lambert, S.J., and Boer, G.J., 2001. CMIP1 evaluation and intercomparison of coupled climate models. Climate Dynamics 17: 83-106.

Lark, T.J., Salmon, J.M., and Gibbs, H.K., 2015. Cropland expansion outpaces agricultural and biofuel policies in the United States. Environmental Research Letters 10(4). doi:10.1088/17489326/10/4/044003.

Lawler, J.J., Lewis, D.J., Nelson, E., Plantinga, A.J., Polasky, S., Withey, J.C., Helmers, D.P., Martinuzzi, S., Pennington, D., and Radeloff, V.C., 2014. Protected land-use change impacts on ecosystem services in the United States. PNAS 111(20): 7492-7497. doi: 10.1073/pnas.1405557111.

Martinuzzi, S., Radeloff, V.C., Higgins, J., Helmers, D., Plantinga, A.J., and Lewis, D.J., 2013. Key areas for conserving United States' biodiversity likely threatened by future land use change. Ecosphere 4(5): 58. 
Martinuzzi, S., Januchowski-Hartley, S., Pracheil, B., McIntyre, P., Plantinga, A., Lewis, D., and Radeloff, V.C., 2014. Threats and opportunities for freshwater conservation under future land use change scenarios in the United States. Global Change Biology, 20(1): 113-124.

Martinuzzi, S., Radeloff, V.C., Joppa, L.N., Hamilton, C.M., Helmers, D.P., Plantinga, A.J., and Lewis, D.J., 2015. Scenarios of future land use change around United States' protected areas. Biological Conservation 184: 446-455.

Mather, A.S., and Needle, C.L., 1998. The forest transition: a theoretical basis. Area 30: $117-$ 124.

McLaughlin, S.B., and Kszos, L.A., 2005. Development of switchgrass (Panicum virgatum) as a bioenergy feedstock in the United States. Biomass and Bioenergy 28, 515-535.

Metzger, M. J., M. D. A. Rounsevell, H. Van den Heiligenberg, M. Pérez-Soba, and P. Soto Hardiman. 2010. How personal judgment influences scenario development: an example for future rural development in Europe. Ecology and Society 15(2): 5. [online] URL: http://www.ecologyandsociety.org/vol15/iss2/art5

Meyfroidt, P., Rudel, T.K., and Lambin, E.F., 2010. Forest transitions, trade, and the global displacement of land use. PNAS 107(49): 20917-20922.

Miguez, F.E., Maughan, M., Bollero, G.A., and Long, S.P., 2012. Modeling spatial and dynamic variation in growth, yield, and yield stability of the bioenergy crops Miscanthus $\mathrm{x}$ giganteus and Panicum virgatum across the conterminous United States. Global Change Biology Bioenergy 4, 509-520.

Moss, R.H., Edmonds, J.A., Hibbard, K.A., Manning, M.R., Rose, S.K., van Vurren, D.P., Carter, T.R., Emori, S., Kainuma, M., Kram, T., Meehl, G.A., Mitchell, J.F.B., Nakicenovic, N., Riahi, K., Smith, S.J., Stouffer, R.J., Thomson, A.M., Weyant, J.P., and WIlbanks, T.J., 2010. The next generation of scenarios for climate change research and assessment. Nature 463, 747756. doi:10.1038/nature08823.

Nakicenovic, N., and Swart, R. (Eds.), 2001. Special Report on Emissions Scenarios (SRES). Cambridge University Press, Cambridge, UK 612 pages.

National Research Council, 2013. Advancing land change modeling: Needs and research requirements. Washington, D.C., National Academy Press (146 pp.).

Nusser, S.M., and Goebel, J.J., 1997. The National Resources Inventory: a long-term multiresource monitoring programme. Environmental and Ecological Statistics 4(3), 181-204.

OECD 2012. "Climate Change Chapter", in OECD Environmental Outlook to 2050: The Consequences of Inaction, OECD Publishing. http://dx.doi.org/10.1787/env_outlook-2012-3-en

Peterson, G.D., Cumming, G.S., and Carpenter, S.R., 2003. Scenario Planning: a Tool for Conservation in an Uncertain World. Conservation Biology 17(2): 358-366.

Radeloff, V.C., Nelson, E., Plantinga, A.J., Lewis, D.J., Helmers, D., Lawler, J.J., Withey, J.C., Beaudry, F., Martinuzzi, S., Butsic, V., Lonsdorf, E., White, D., and Polasky, S., 2012. 
Economic-based projections of future land use in the conterminous United States under alternative policy scenarios. Ecological Applications 22(3), p 1036-1049.

Ramankutty, N., Heller, E., and Rhemtulla, J., 2010. Prevailing myths about agricultural abandonment and forest regrowth in the United States. Annals of the Association of American Geographers 100(3): 502-512.

Rao, S., and Riahi, K., 2006. The role of non-CO2 greenhouse gases in a climate change mitigation: Long-term scenarios for the $21^{\text {st }}$ century. Multigas mitigation and climate policy. The Energy Journal 3 (Special Issue). 177-200.

Rastetter, E. B. 2003. The collision of hypotheses: What can be learned from comparisons of ecosystem models? Pages 211-224 In: C. D. Canham, J. J. Cole, and W. K. Lauenroth (Editors). Models in Ecosystem Science. Princeton University Press, Princeton, NJ

Riahi, K., Gruebler, A., and Nakicenovic, N., 2007. Scenarios of long-term socioeconomic and environmental development under climate stabilization. Technological Forecasting and Social Change 74(7): 887-935.

Rounsevell, M.D.A., Reginster, I., Araujo, M.B., Carter, T.R., Dendoncker, N., Ewert, F., House, J.I., Kankaanpaa, S., Leemans, R., Metzger, M.J., Schmit, C., Smith, P., and Tuck, G., 2006. A coherent set of future land use change scenarios for Europe. Agriculture, Ecosystems, and Environment 114: 57-68.

Rounsevell, M.D.A., Pedroli, B., Erb, K.H., Gramberger, M., Busck, A.G., Haberl, H., Kristensen, S., Kuemmerle, T., Lavorel, S., Lindner, M., Lotze-Campen, H., Metzger, M.J., Murray-Rust, D., Popp, A., Perez-Soba, M., Reenberg, A., Vadineanu, A., Verburg, P.H., and Wolfslehner, B., 2012. Challenges for land system science. Land Use Policy 29: 899-910.

Schmitz, C., van Meijl, H., Kyle, P., Nelson, G.C., Fujimori, S., Gurgel, A., Havlik, P., Heyhoe, E., Mason d-Croz, D., Popp, A., Sands, R., Tabeau, A., van der Mensbrugghe, D., von Lampe, M., Wise, M., Blanc, E., Hasegawa, T., Kavallari, A., and Valin, H., 2014. Land-use change trajectories up to 2050: insights from a global agro-economic model comparison. Agricultural Economics 45: 69-84.

Seto, K.C., Reenberg, A., Boone, C.G., Fragkias, M., Haase, D., Langanke, T., Marcotullio, P., Munroe, D.K., Olah, B., and Simon D., 2012. Urban land teleconnections and sustainability. PNAS 109(20): 7687-7692.

Sleeter, B.M., Sohl, T.L., Bouchard, M., Reker, R, Sleeter, R.R., and Sayler, K.L., 2012, Scenarios of land use and land cover change in the conterminous United States: Utilizing the Special Report on Emission Scenarios at Ecoregional Scales: Global Environmental Change 22(4), p. 896-914.

Smith, S.J., and T.M.L. Wigley 2006. Multi-gas forcing stabilization with the MiniCAM. The Energy Journal (Special Issues \#3) pp. 373-391.

Sohl, T.L., and Claggett, P.R., 2013, Clarity versus complexity: Land-use modeling as a practical tool for decision-makers, Journal of Environmental Management 129, p. 235-243. 
Sohl, T.L., Sayler, K.L., Bouchard, M.A., Reker, R.R., Friesz, A.M., Bennett, S.L., Sleeter, B.M., Sleeter, R.R., Wilson, T.S., Knuppe, M., and Van Hofwegen, T., 2014. Spatially explicit modeling of 1992 to 2100 land cover and forest stand age for the conterminous United States. Ecological Applications: 24(5): 1015-1036. http://dx.doi.org/10.1890/13-1245.1

Sohl, T.L., 2014. The relative impacts of climate and land-use change on conterminous United States bird species from 2001 to 2075. PLoS ONE 9(11): e112251. doi:10.1371/journal.pone.0112251.

Spearman, C., 1904. The proof and measurement of association between two things. The American Journal of Psychology 15(1): 72-101.

Steward, D.R., and Allen, A.J., 2015. Peak groundwater depletion in the High Plains Aquifer, projections from 1930 to 2110 . Agricultural Water Management $13 \mathrm{pp}$.

http://dx.doi.org/10.1016/j.agwat.2015.10.003.

Stohlgren, T.J., Ma., P., Kumar, S., Rocca, M., Morisette, J.T., Jarnevich, C.S., and Benson, N., 2010. Ensemble habitat mapping of invasive plant species. Risk Analysis 30(2): 224-235.

Strengers, B., Leemans, R., Eickhout, B., de Vries, B., and Bouwman, L., 2004. The land-use projections and resulting emissions in the IPCC SRES scenarios as simulated by the IMAGE 2.2 model. GeoJournal 61: 381-392.

Tan, Z., Liu, S., Sohl, T.L., Wu, Y., and Young, C.J., 2015. Ecosystem carbon stocks and sequestration potential of federal lands across the conterminous United States. Proceedings of the National Academy of Sciences of the United States of America 112(41): 12723-12728.

Taylor, K.E., Stouffer, R.J., and Meehl, G.A., 2012. An overview of CMIP5 and the experiment design. Bulletin of the American Meteorological Society 93: 485-498.

TeBrommelstroet, M.T., 2010. Equip the warrior instead of manning the equipment. The journal of Transport and Land Use 3(1): 25-41.

Theobald, D.M. 2001. Land-use dynamics beyond the American urban fringe. Geographical Review 91: 544-564.

Theobald, D.M. 2005. Landscape patterns of exurban growth in the USA from 1980 to 2020. Ecology and Society 10(1): 32.

Thompson, J.R., Wiek, A., Swanson, F.J., Carpenter, S.R., Fresco, N., Hollingsworth, T., and Foster, D.R., 2012. Scenario studies as a synthetic and integrate research activity for long-term ecological research. BioScience 62(4): 367-376.

Thuiller, W., 2003. BIOMOD: Optimising predictions of species distributions and projecting potential future shifts under global change. Global Change Biology 9, 1353-1362.

Thuiller, W., Lafourcade, B., Engler, R., and Araujo, M.B., 2009. BIOMOD - A platform for ensemble forecasting of species distributions. Ecography, 32, 369-373. 
Van Vurren, D., den Elzen, M., Lucas, P., Eickhout, B., Strengers, B., van Ruijven, B., Wonink, S., and van Houdt, R., 2007. Stabilizing greenhouse gas concentrations at low levels: an assessment of reduction strategies and costs. Climatic Change 81: 119-159. doi:10.1007/s/10584-006-9172-9.

Van Vurren, D., Stehfest, E., den Elzen, M.G.J., Kram, T., van Vliet, J., Deetman, S., Isaac, M., Klein Goldewijk, K., Hof, A., Mendoza Beltran, A., Oostenrijk, R., and van Ruijven., B., 2011. RCP2.6: Exploring the possibilities to keep global mean temperature increase below $2^{\circ} \mathrm{C}$. Climatic Change 109: 95-116. doi:10.1007/s10584-011-0152-3.

Verburg, P.H., Eickhout, B., and van Meijl, H., 2008. A multi-scale, multi-model approach for analyzing the future dynamics of European land use. Annals of Regional Science 42, 57-77.

Viger, R.J., Hay, L.E., and Markstrom, S.L., 2011. Hydrologic effects of urbanization and climate change on the Flint River basin, Georgia. Earth Interactions 15, paper number 20 (25 pp).

Vogelmann, J.E., Howard, S.M., Yang, L., Larson, C.R., Wylie, B.K., and Van Driel, N., 2001. Completion of the 1990s national land cover data set for the conterminous United States from Landsat thematic mapper and ancillary data sources. Photogrammetric Engineering and Remote Sensing 67, 650-662.

Waisanen, P.J., and Bliss, N.B., 2002. Changes in population and agricultural land in conterminous United States counties, 1790 to 1997. Global Biogeochemical Cycles 16(4): 84-1 to $84-19$.

Wear, D.N., 2011. Forecasts of county-level land uses under three future scenarios: a technical document supporting the forest service 2010 RPA assessment. General Technical Report SRS141. USDA Forest Service, Southern Research Station, Asheville, North Carolina, USA.

West, T.O., Le Page, Y., Huang, M., Wolf, J., and Thomson, A.M., 2014. Downscaling global land cover projections from an integrated assessment model for use in regional analyses: results and evaluation for the US from 2005 to 2095. Environmental Research Letters 9, 064004 (15 pp): doi:10.1088/1748-9326/9/6/064004.

West, T.O., and Le Page, Y., 2014. NACP CMS: Land Cover Projections (5.6-km) from GCAM v3.1 for the Conterminous US, 2005-2095. Data set. Available online [http://daac.ornl.gov] from Oak Ridge National Laboratory Distributed Active Archive Center, Oak Ridge, Tennessee, USA. http://dx.doi.org/10.3334/ORNLDAAC/1216.

Wright, C.K., and Wimberly, M.C., 2013. Recent land use change in the Western Corn Belt threatens grasslands and wetlands. PNAS 110(10): 4134-4139.

Zellner, M.L., 2008. Embracing complexity and uncertainty: The potential of agent-based modeling for environmental planning and policy. Planning Theory \& Practice 9(4), 437-457.

Zhao, S., Liu, S., Sohl, T., Young, C., and Werner, J., 2013. Land use and carbon dynamics in the southeastern United States from 1992 to 2050. Environmental Research Letters 8, 044022 (9 pp): doi:10.1088/1748-9326/8/4/044022. 


\section{Figure Captions}

Figure 1 - Modeled LULC Change - Modeled LULC change for 2000, 2050, and 2100. Each panel represents a different LULC class: A) Agriculture (cropland and pasture combined), B) Cropland, C) Pasture, D) Forest/Range (forest and rangeland combined), E) Forest, F) Range, and G) Urban. Note that not all LULC classes are represented by each model. The NRI Econometric Model and Forest Service RPA projections do not model past 2050. See Table 3 for a description of each scenario.

Figure 2 - Pairwise Spearman's rank correlation by LULC class - Pairwise Spearman's rank correlation of county-level LULC change from 2000 to 2050 for each possible scenario pair. Each LULC class and model is depicted with the range of rank correlation values (minimum to maximum), as well as mean value across all scenario pairs. Classes not explicitly modeled by a given scenario set are marked as "N/A".

Figure 3 - Pairwise Spearman's rank correlation by common scenario - Pairwise Spearman's rank correlation of county-level LULC change from 2000 to 2050 for agriculture, forest/range, and urban for the three SRES scenarios modeled by FORE-SCE, FS-RPA, IMAGE, and ICLUS models. Gray bars represent the entire range of pairwise rank correlation values across the three possible scenario pairs. Black bars represent the exact value for each given pair. ICLUS is only provided for urban, while IMAGE is only shown for agriculture and forest/range.

Figure 4-Spatial distribution of cropland change - Spatial distribution of cropland change ( 2000 to 2050) for the four projection families that explicitly modeled that class. Note the IMAGE model used for the IPCC AR4 report did not provide spatially modeled cropland (only aggregated "agriculture") and is thus not depicted in this figure.

Figure 5 - Spatial distribution of pasture change - Spatial distribution of pasture change ( 2000 to $\sim 2050$ ) for the four projection families that explicitly modeled that class. Note the IMAGE model used for the IPCC AR4 report did not provide spatially modeled pasture (only aggregated "agriculture") and was thus not depicted in this figure.

Figure 6 - Spatial distribution of forest change - Spatial distribution of forest change ( 2000 to $\sim 2050)$ for the four projection families that explicitly modeled that class. Note the RCP models did not provide spatially modeled forest (only aggregated "primary" and "secondary" land) and were thus not depicted in this figure.

Figure 7-Spatial distribution of rangeland change - Spatial distribution of rangeland change ( 2000 to 2050) for the four projection families that explicitly modeled that class. Note the RCP models did not provide spatially modeled range (only aggregated "primary" and "secondary" land) and were thus not depicted in this figure.

Figure 8-Spatial distribution of urban change - Spatial distribution of urban change ( 2000 to 2050) for the five projection families that explicitly modeled that class. Note that only two of the four RCP models explicitly modeled urban change.

Figure 9-Cropland compared with historical maximum - Historical maximum extent of cropland by county for the four projection families that explicitly modeled cropland compared with modeled results for 2050. Black represents counties where historical maximums in the Waisanen and Bliss (2002) database were already exceeded by more than $25 \mathrm{~km}^{2}$ at the start of the simulation period, indicating database consistency issues between the various LULC databases. Magenta counties represent areas 
where initially cropland area was below historical maximums, but where the model application itself caused a county to exceed the historical maximum (by more than $25 \mathrm{~km}^{2}$ ) by 2050 . 

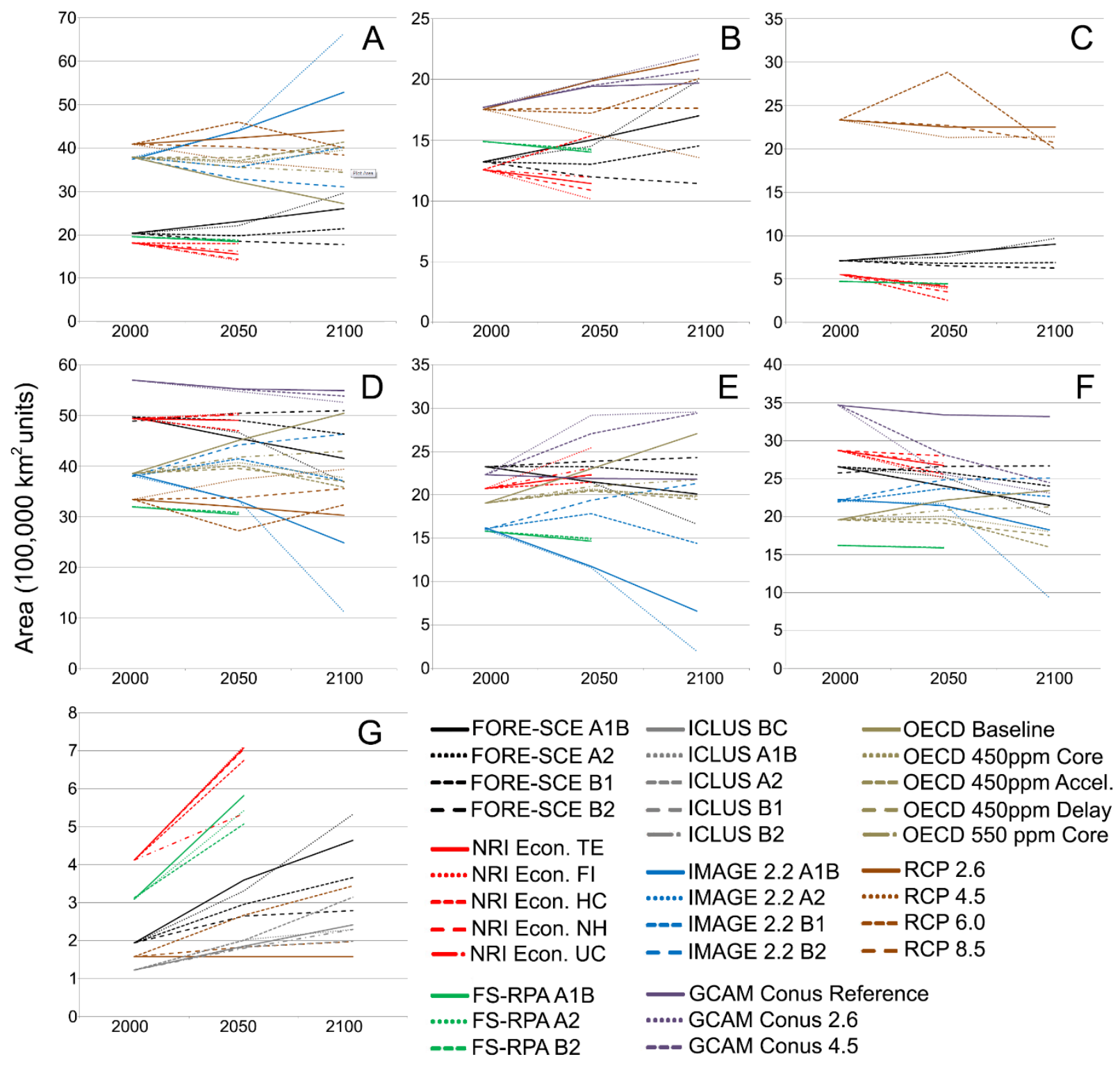


\section{0 to 2050 Change}
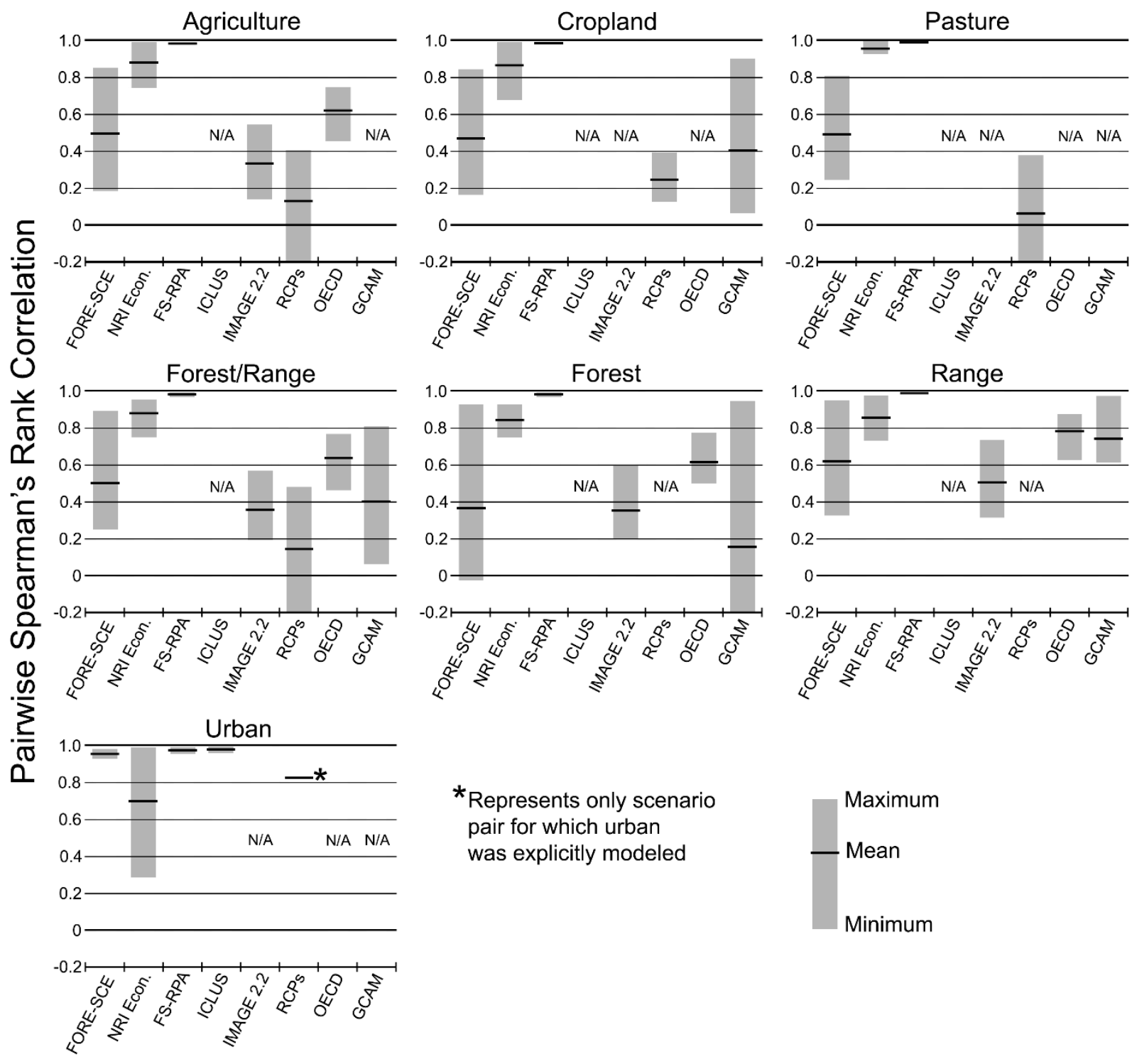

Forest
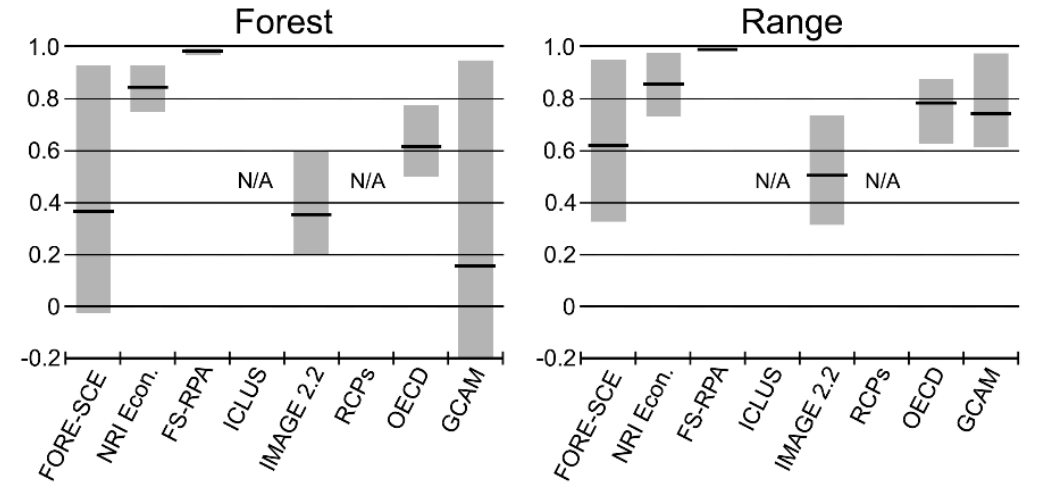

$0.2 \longrightarrow$

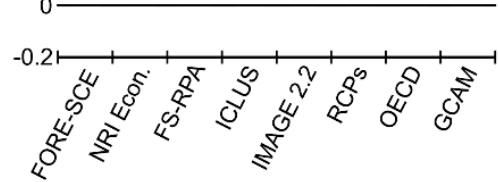
${ }^{*}$ Represents only scenario pair for which urban was explicitly modeled

\section{Maximum \\ Mean \\ Minimum}




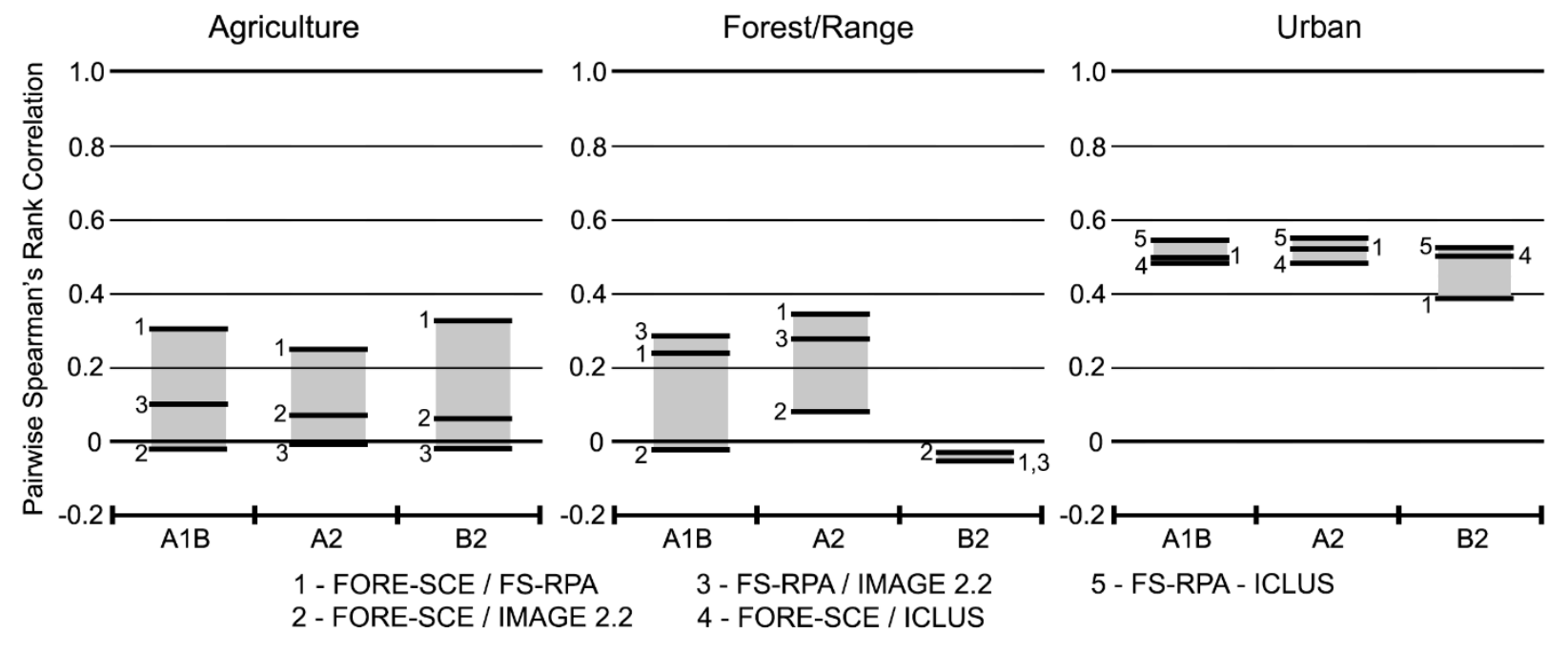




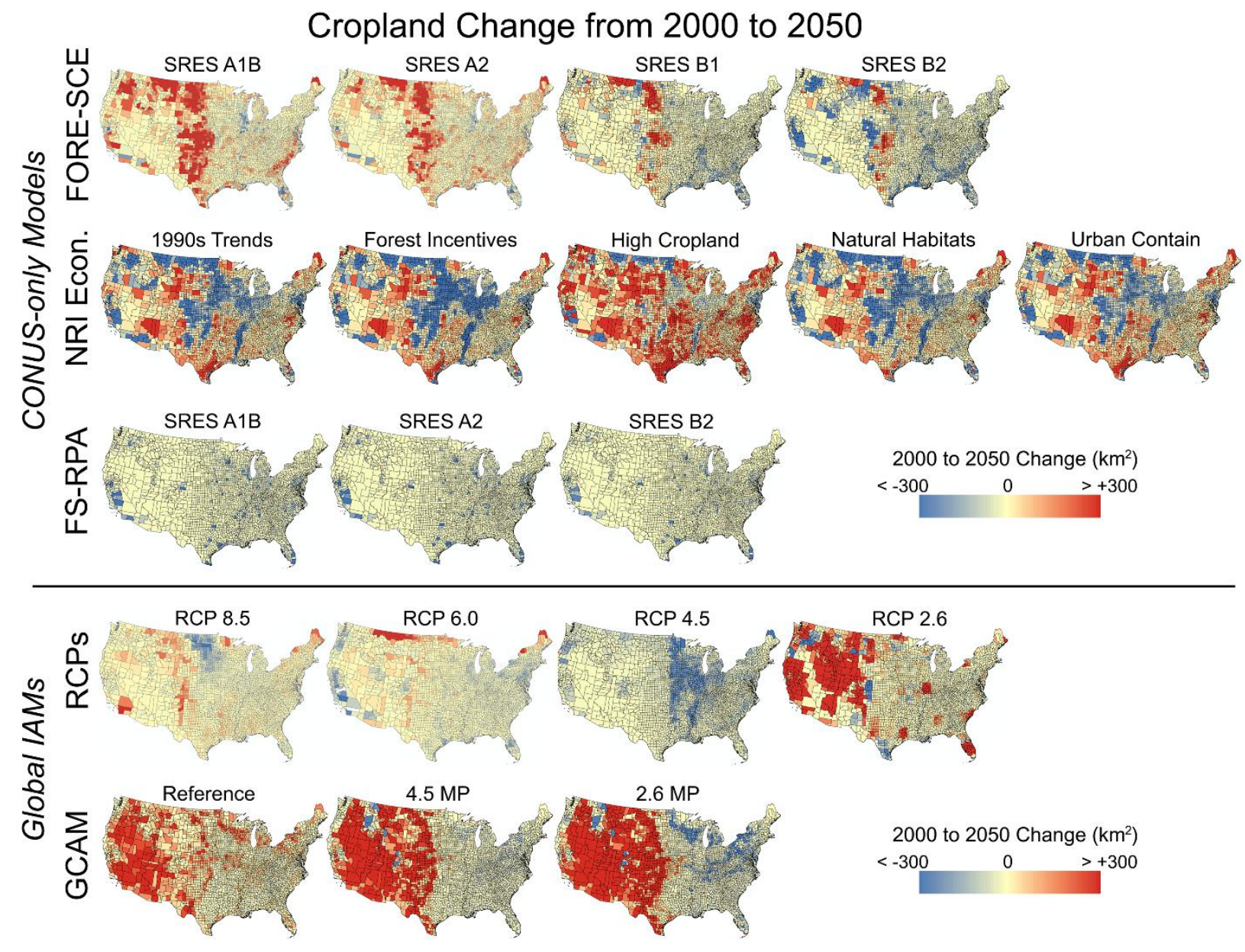




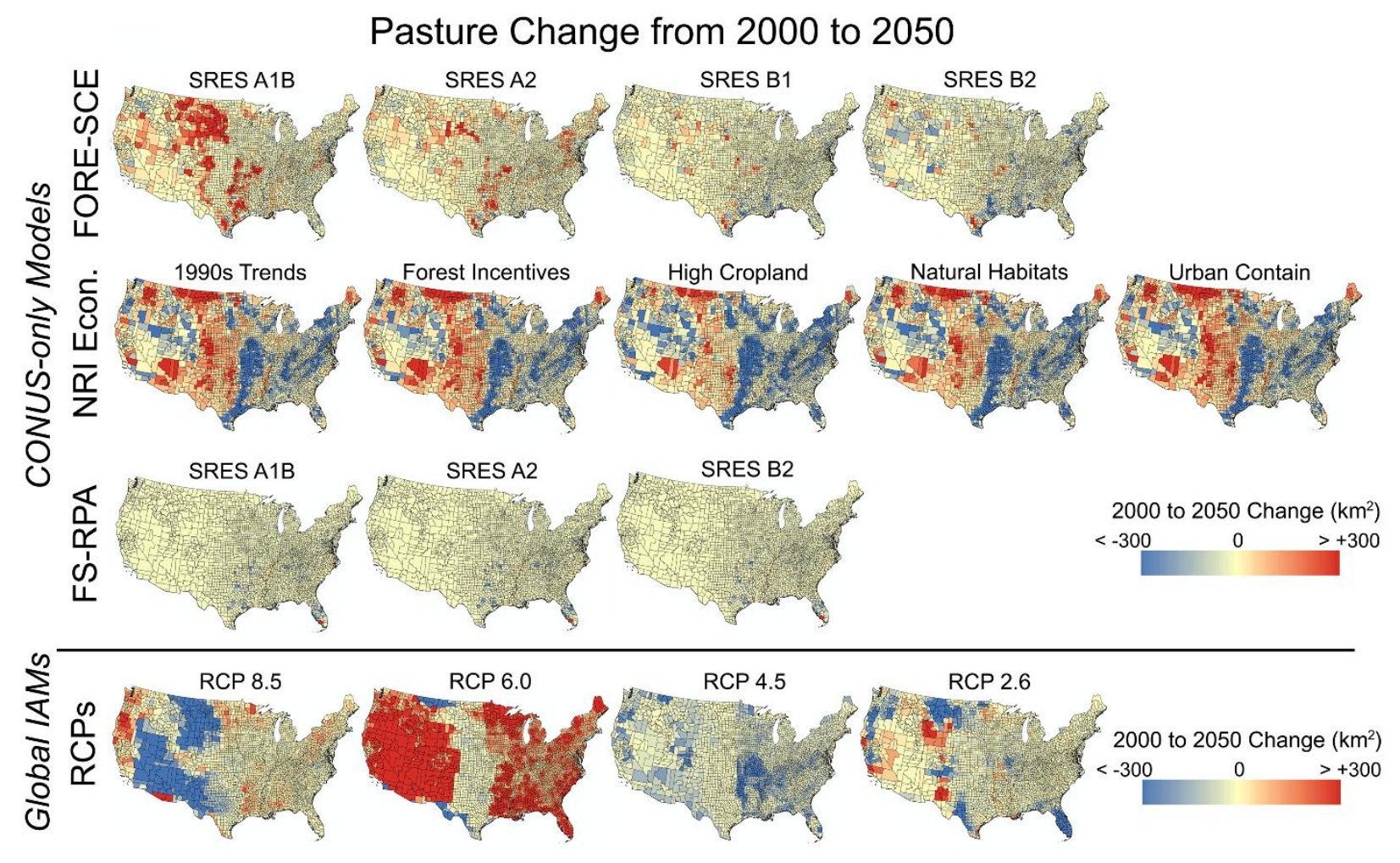




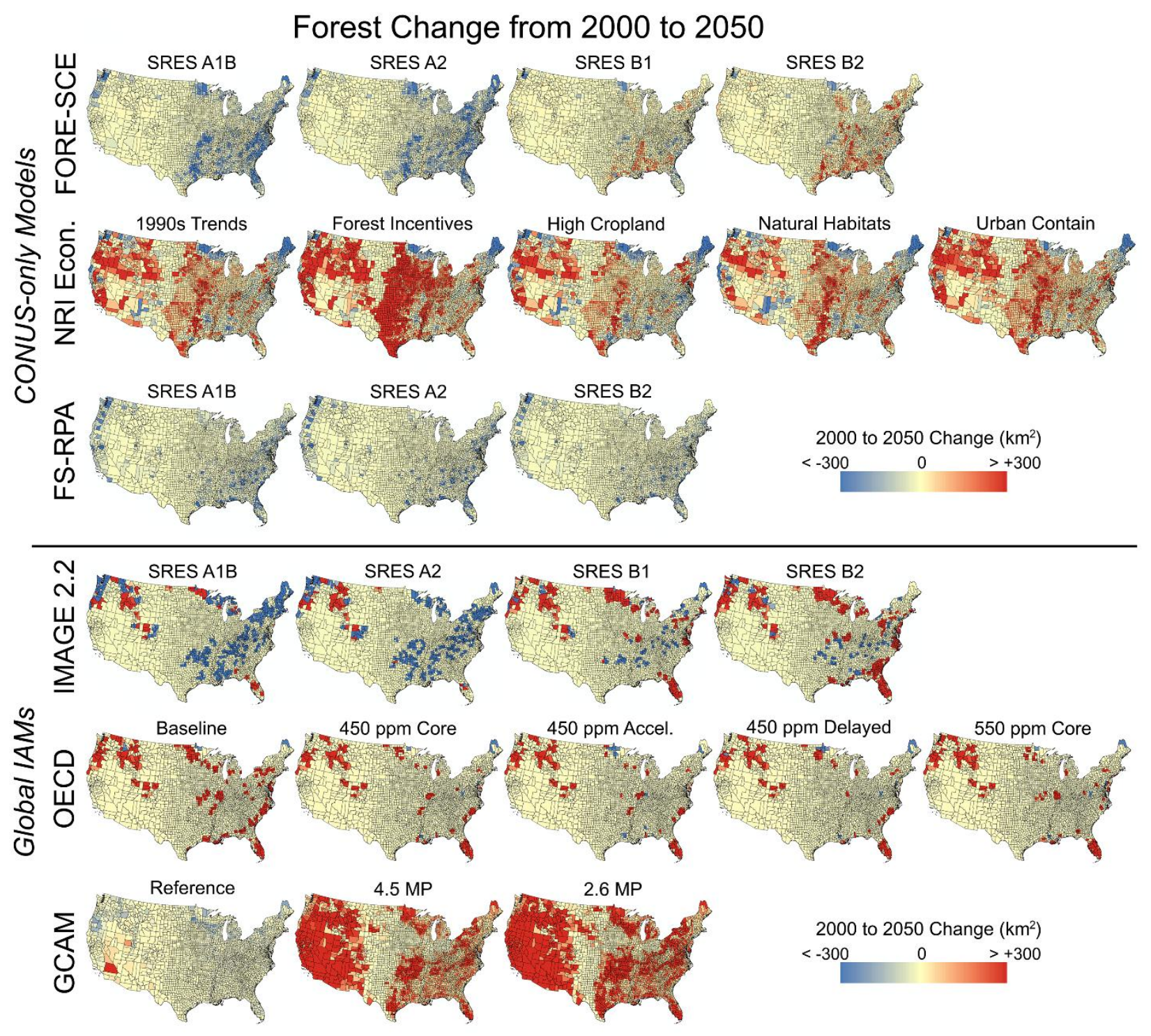




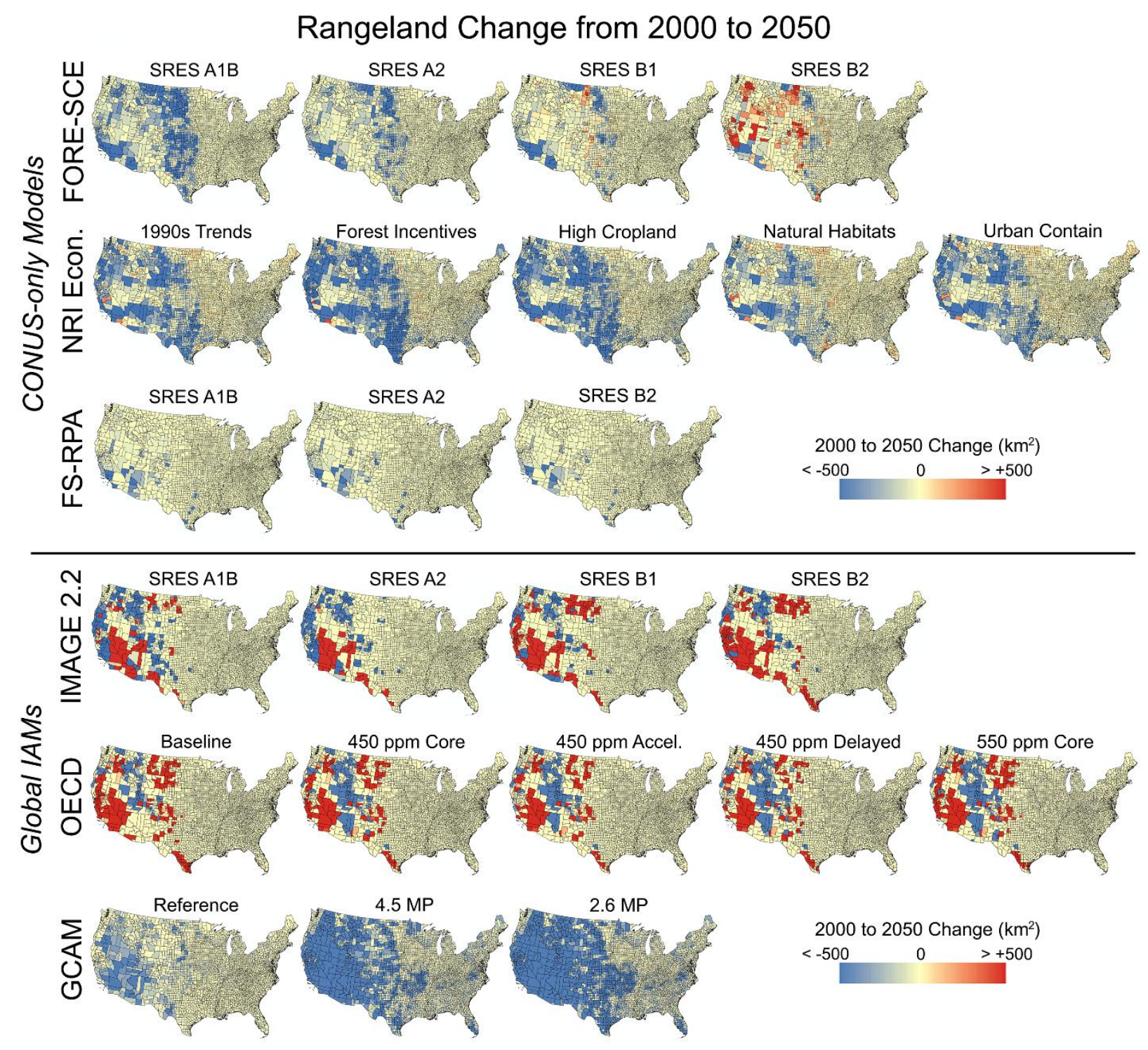




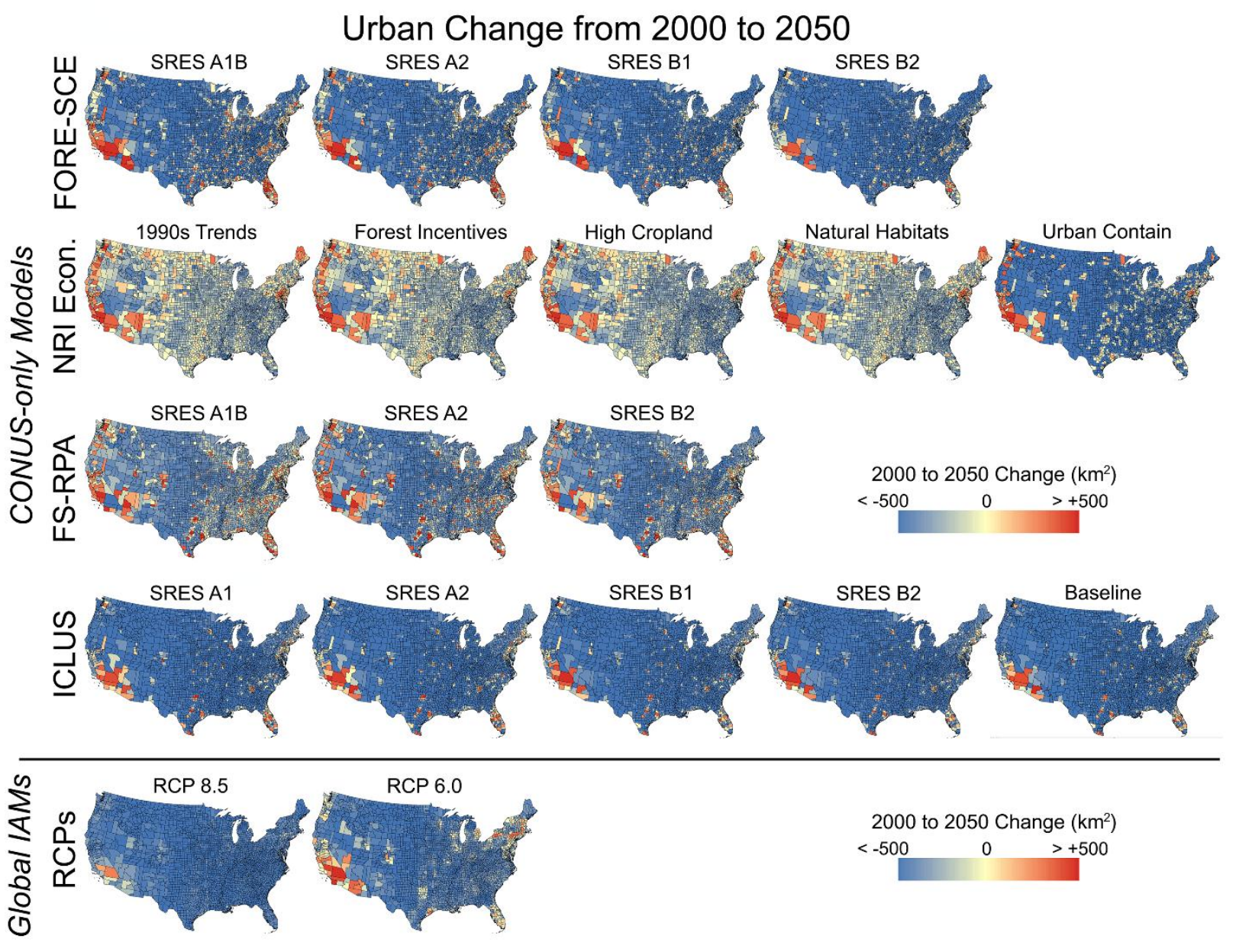




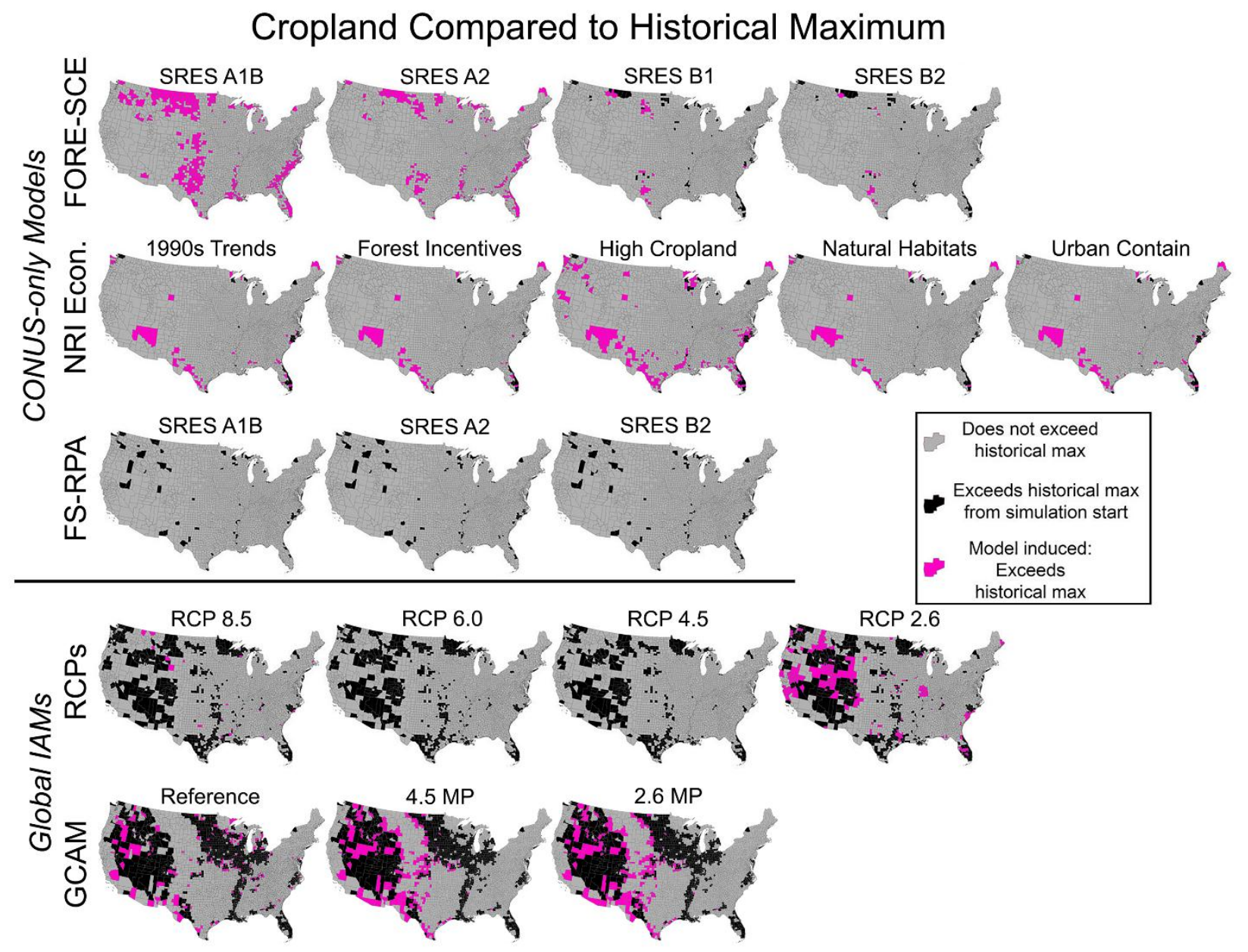

